\title{
Learning about social-ecological trade-offs
}

\author{
Diego Galafassi $^{1}, \underline{\text { Tim M. Daw }}^{1}, \underline{\text { Lydiah Munvi }}^{2}$, Katrina Brown $^{3}$, Cecile Barnaud $^{4}{\text { and } \underline{\text { Ioan Fazev }}^{5}}^{5}$
}

\begin{abstract}
Trade-offs are manifestations of the complex dynamics in interdependent social-ecological systems. Addressing tradeoffs involves challenges of perception due to the dynamics of interdependence. We outline the challenges associated with addressing trade-offs and analyze knowledge coproduction as a practice that may contribute to tackling trade-offs in social-ecological systems. We discuss this through a case study in coastal Kenya in which an iterative knowledge coproduction process was facilitated to reveal social-ecological trade-offs in the face of ecological and socioeconomic change. Representatives of communities, government, and NGOs attended two integrative workshops in which methods derived from systems thinking, dialogue, participatory modeling, and scenarios were applied to encourage participants to engage and evaluate trade-offs. Based on process observation and interviews with participants and scientists, our analysis suggests that this process lead to increased appreciation of interdependences and the way in which trade-offs emerge from complex dynamics of interdependent factors. The process seemed to provoke a reflection of knowledge assumptions and narratives, and management goals for the social-ecological system. We also discuss how stakeholders link these insights to their practices.
\end{abstract}

Key Words: complexity thinking; coproduction; knowledge; participatory modeling; scenarios; well-being

\section{INTRODUCTION}

Worldwide, the livelihoods and well-being of communities are deeply intertwined with ecosystems, which in turn are affected by institutions and ecological change (Berkes et al. 2000). In these interdependent social-ecological systems, management or policy interventions in one element may directly or indirectly affect other elements of the system (Axelrod and Cohen 2000, Brown et al. 2001). One key component of the search for fair and sustainable pathways in interdependent social-ecological systems is to learn to engage with trade-offs that emerge from interventions, be they everyday actions by ecosystem users or high-impact actions endorsed by policy makers. Trade-offs emerge when an action, for example, a management intervention, enhances one aspect to the detriment of another. Take for example a coastal system in which people rely on ecological resources for their livelihoods. In such a system, interdependences are defined by, for instance, access to resources, norms, and rules of interaction. A policy designed to improve ecological status might lead to improvements on the well-being of some people and to a decrease in the wellbeing of others. This is what we call a social-ecological trade-off. We focus on how capacities to address social-ecological trade-offs might be developed in designed processes of knowledge coproduction amongt governance actors and scientists.

Management of social-ecological systems necessarily involves trade-offs, and the consideration and resolution of trade-offs is likely to be influenced by the politics of decision making and the relative power of winners and losers to articulate and pursue their interests. Thus, dealing with trade-offs is an important part of governance (Brown et al. 2001, Daw et al. 2011) and appraisal of trade-offs between different stakeholder groups is seen as an important strategy in poverty alleviation and sustainable management of a social-ecological system (Rodríguez et al. 2006, Raudsepp-Hearne et al. 2010, Daw et al. 2011). Policy designed without considering trade-offs is more likely to fail because of conflicts, or to cause harm to vulnerable people (McShane et al. 2011). Following earlier calls for more attention to trade-offs (Carpenter et al. 2009), recent literature deals with trade-offs between different ecosystem services (Rodríguez et al. 2006, Raudsepp-Hearne et al. 2010), between human well-being of different people (Coulthard et al. 2011, Daw et al. 2011), or between different values (Tetlock 2003).

The need to make trade-offs transparent and visible in decision making is paramount. By identifying particular system dynamics that lead to trade-offs, options to transform these dynamics through novel solutions can be explored to mitigate or even eliminate a trade-off. At other times, a choice needs to be made in light of trade-offs. Still, in these cases, making explicit the analysis of winners and losers of a given decision challenges a governance system to consider those losing out and to consider adaptively monitoring the unfolding trade-off decisions.

The more widely used tools for dealing with trade-offs are analytical approaches, such as cost and benefits, multicriteria analysis, and quantification of ecosystem services values. These tools weigh pros and cons of different courses of action, highlighting potential aggregated trade-offs and synergies (Brown et al. 2001, Goldstein et al. 2012). However, conventional costbenefit analysis tends to depart from a more technical perspective, with limited appreciation for the range of social and cultural linkages between different social groups and between people and ecosystems, and the analysis often disregards the distribution of benefits and costs (Lele and Srinivasan 2013). Such analysis may further exclude and enhance the vulnerability of certain groups. On the other hand, including multiple perspectives, through the involvement of multiple actors in a knowledge coproduction setting can allow for the consideration of interdependences between elements of a social-ecological system that underpin the dynamics of synergies or trade-offs. This might be key to help

\footnotetext{
${ }^{1}$ Stockholm Resilience Centre, Stockholm University, ${ }^{2}$ Independent Natural Resource Governance Consultant, Basingstoke, ${ }^{3}$ Geography, College of Life and Environmental Sciences, University of Exeter, ${ }^{4}$ INRA (French National Institute for Agricultural Research), ${ }^{5}$ Centre for Environmental Change and Human Resilience, University of Dundee
} 
Table 1. Trade-offs challenges and potential strategies for addressing them.

\begin{tabular}{|c|c|c|}
\hline & Trade-offs challenges & Potential strategies for addressing these challenges \\
\hline \multicolumn{3}{|l|}{ Perception } \\
\hline & Trade-offs can be cognitively "invisible" & $\begin{array}{l}\text { Understand the world in a systemic perspective; evaluate how particular } \\
\text { actions would affect different people in different ways }\end{array}$ \\
\hline & Trade-offs can be perceived differently by different people & Acknowledge multiple perspectives and experiences \\
\hline & Incentives, institutions, and narratives can "hide" trade-offs & Reflect on assumptions and narratives \\
\hline \multicolumn{3}{|c|}{$e_{1}$} \\
\hline & Innovative solutions may be needed to address trade-offs & $\begin{array}{l}\text { Acknowledge that there are no straightforward solutions; foster creative } \\
\text { thinking aimed at finding novel solutions }\end{array}$ \\
\hline & Diverse and conflicting goals and principles for action & $\begin{array}{l}\text { Deal with cognitive-emotional dimensions of tradeoffs; foster deliberation } \\
\text { between perspectives that can accommodate and work with a plurality of } \\
\text { perspectives }\end{array}$ \\
\hline & $\begin{array}{l}\text { Challenges of implementation including institutional } \\
\text { challenges and additional unforeseen trade-offs }\end{array}$ & $\begin{array}{l}\text { Learn in practice about institutional, economic, political, and cultural } \\
\text { aspects of implementation; monitor and review actions as new trade-offs } \\
\text { emerge }\end{array}$ \\
\hline & Power dynamics between stakeholders & $\begin{array}{l}\text { Create spaces and learning environments that equalize certain kinds of } \\
\text { power plays; ensure participation from marginalized stakeholders }\end{array}$ \\
\hline
\end{tabular}

identify who and how particularly vulnerable people are being affected and analyze certain feedback dynamics that might keep them in a vulnerable position, as well as to identify levers of change (Meadows 2008).

Daw et. al. (2015) proposed an approach for engaging with socialecological trade-offs from a systemic perspective. The approach integrates ecological modeling, in-depth individual and community well-being research, and a series of participatory modeling workshops designed to foster knowledge coproduction between scientists, experts, and representatives of various sectors that have an influence in local policy and management in coastal Kenya. We focus on the types of learning observed in such participatory processes and explore the ways in which the various tools of dialogue, participatory model construction, and scenarios may respond to the particular challenges of addressing trade-offs.

\section{LEARNING TO DEAL WITH SOCIAL-ECOLOGICAL TRADE-OFFS}

Dealing with trade-offs requires learning to identify and understand trade-offs. Developing sensitivity and greater understanding of complexity can help to identify costs and benefits of different actions and identify potential trade-offs, but will not be sufficient to help those involved in making decisions about how to move forward. In fact, going ever deeper into the nuances can be disabling. In interdependent social-ecological systems, any action is potentially associated with multiple trade-offs, which may lead to a sense of paralysis (Fazey et al. 2011). To this end, learning to deal with trade-offs involves learning to put insights into practice.

Knowledge coproduction processes, involving multiple actors and scientists, can be a strategy for developing sensitivity to trade-offs and to learn how to put these insights into practice (Stave 2002, Kenter et al. 2015). In the context of participatory modeling, Daré et al. (2013) discussed how learning to deal with systemic interdependencies (as in trade-offs) demands a process through which diverse stakeholders, through communicative action (Habermas 1984) can reach collective action. This process inevitably involves conflicts of interests and power plays that need to be considered (Barnaud and Van Paassen 2013).
The challenge of "knowing" and the practice of trade-offs

Trade-offs imply a decision with varying degrees of information about the upsides and downsides of a particular choice. These decisions are inherently bound up in power dynamics and often pose a social dilemma (Rittel and Webber 1973, Höijer et al. 2006). Although interrelated, a distinction can be made between the identification of trade-offs and making decisions in the face of trade-offs. We refer to these as the challenges of perception and practice of trade-offs (Table 1).

Challenges of perception have at least three facets. First, tradeoffs might be invisible to those making decisions, in that decisions might be made without the awareness of the systemic consequences of particular actions (Meadows 2008). As with other emergent properties of complex systems, analyzing tradeoffs requires the simultaneous consideration of system feedbacks and dynamics of processes at various temporal and spatial scales, which can be cognitively challenging (Sterman 1994). This relates to the difficulty of tracing indirect implications of trade-offs when, for instance, a policy has an impact on aspects of the socialecological system at multiple temporal and spatial scales.

Second, trade-offs can be diversely perceived. The subjective experience of trade-offs implies that different people see wins and losses differently. What appears as a trade-off from one perspective appears as a win-win from another. These perspectives vary according to knowledge, values, and beliefs, but also can vary in relation to one's material assets, property or usufruct rights, and other (individual and social) livelihood capacities. This is particularly important when trade-offs decisions affect marginalized people who lack the political power to represent their views in the decision process.

Third, trade-offs are not always explicit, and can be hidden, intentionally ignored, or downplayed, meaning that institutions, incentive structures, political processes, and social narratives can mask and hide trade-offs from decision-making processes (Schoemaker and Tetlock 2012). For instance, narratives that emphasize win-win solutions are often more socially and psychologically attractive, but may be based on weak assumptions and little evidence and hide an actual trade-off (Tetlock 2003, Muradian 2013, Daw et al. 2015). 
Developing the perception and a greater understanding of tradeoff dynamics need eventually translate into practice. This may include developing ideas for solutions that range from mitigation of gains and loses, all the way to transforming system dynamics in ways that might eliminate the trade-off. Further, deliberating about trade-offs in practice requires collective learning to face dilemmas jointly and to develop shared principles and goals for action (Howe et al. 2014), which may be challenging in conflictual situations or situations in which unequal power between stakeholders is not addressed. The coordination of actions across multiple actors and institutions is crucial for implementation and to create structures that support those who lose out (Daré et al. 2013). Further, it is in practice that actors learn about the institutional dimensions, incentive structures, and power dynamics that hamper or allow for trade-offs responses.

\section{Knowledge coproduction to deal with trade-offs}

These challenges of perception and practice of trade-offs have implications for learning for both individuals and for the broader networks of actors. We analyze how a process of knowledge coproduction might respond to these challenges.

Knowledge coproduction between scientists and governance actors is increasingly acknowledged as a key social process to deal with complex sustainability challenges (Cash et al. 2003, Fazey et al. 2013, Reyers et al. 2015). Fazey et al. (2013:70) defined knowledge coproduction as "a process where knowledge is or can be produced through interaction with others, possibly with people with different perspectives and backgrounds, through cooperative endeavours and mutual learning."

An emerging literature provides some evidence that these processes of knowledge coproduction can lead to interrelated changes in cognitive and relational dimensions of a given social-ecological system (Muro and Jeffrey 2008, Reed et al. 2010, Ison et al. 2013). The cognitive dimension involves changes in knowledge, acquisition of new information, changes in mental models, development of new values, and underlying assumptions about how the world works. Relational changes refers to changes in personal or professional networks, as well as changes in qualities of relationships, for example increased trust, or better understanding of another's views, beliefs, and values (Daré et al. 2013).

In trade-offs that are invisible (see Table 1), knowledge coproduction can reveal systems connections and dynamics that lead to trade-offs. In hidden trade-offs, a knowledge coproduction process can call into question and review guiding assumptions and narratives about certain actors' goals, priorities, and how they view the world (Argyris 1976, Cook-Greuter 2000, Fazey 2010). Last, because trade-offs are perceived differently, a knowledge coproduction process is a potential space in which participants might become aware of how a given trade-off is experienced and perceived by others, their values, intentions, knowledge, and commitments. In particular, knowledge coproduction raises the opportunity to include the voices of those who do not have a secured space in political and decision-making processes.

Relational changes are crucial for putting insights into practice and may be reflected in the emergence of collaborations, new institutions, or innovative collaborative projects. Participants of a learning situation bring experiences, life histories, and narratives that actively shape the coconstruction of knowledge. Through a process of dialogue and communication, people come to see an enriched picture (Tengö et al. 2014), i.e., a shared logic and reasoning about the structure and dynamics of social-ecological systems (Daré et al. 2013). Importantly, in relation to trade-offs, knowledge coproduction brings together diverse ways of knowing (Tàbara and Chabay 2013, Tengö et al. 2014), which may support understanding and prioritization of vulnerable and excluded actors.

The set of tools that are commonly used in processes coproduction draw from traditions of dialogue (Bohm 1996), systems thinking (Walker and Salt 2012), participatory modeling (Barreteau et al. 2003, Etienne et al. 2011), games and interactive tools (Barreteau and Bousquet 2001, Lankford and Watson 2007, Mathevet et al. 2007), and scenario planning (Peterson et al. 2003) among others. However, there is still a conceptual and empirical gap on how various tools and participatory approaches contribute to the development of understanding about trade-off dynamics and the capacities to deal with them.

Reflecting on the challenges of addressing trade-offs (Table 1), we propose that knowledge coproduction processes can support tackling trade-offs, by: (1) developing a systemic perspective and reviewing assumptions of how the system works; (2) understanding how trade-offs have an impact on different people differently; (3) supporting the development of a collaboration and new relations among stakeholders; (4) supporting the development of shared goals; and (5) stimulating new practices that address trade-off dynamics. We describe a case study in coastal Kenya and discuss findings in the light of these dimensions of learning.

\section{METHODS}

\section{The context}

We based our analysis of the contribution of knowledge coproduction to learning about trade-offs on a process developed within the context of the "Participatory modeling of wellbeing trade-offs in Coastal Kenya" project (http://www.espa.ac.uk/ projects/ne-i00324x-1/further-information-and-project-documents). The overall project combined ecological modeling, qualitative well-being research with local communities (Abunge et. al. 2013), and participatory modeling and scenarios development to understand and reveal trade-offs in ecosystem services and wellbeing of different groups (Daw et al. 2015). We focus on learning dimensions of the two integrative participatory workshops that brought together scientists and secondary stakeholders, i.e., governance actors whose well-being is not directly affected by changes in ecosystems, but have direct impact in policy, management, and decision making on a range of coastal issues. The overall systemic approach to trade-offs is described in Daw et al. 2015. We will detail the tools used in the workshops and analyze the types of learning observed.

\section{The case}

Our focal coastal system is a fishery located next to the rapidly urbanizing port city and tourism hub of Mombasa, Kenya. Typical of many small-scale fisheries, the system includes a large number of poor stakeholders with limited alternative occupations and a heavily exploited ecosystem (McClanahan 2010, Daw et al. 2015). The site is located close to Mombasa Marine National Park, which has been an actively managed no-take park since 1991 (McClanahan and Mangi 2001), and partially within the adjacent 
Fig. 1. Two workshops process design. From top to bottom, the first workshop was about understanding the system, with a focus on imagination, creativity, and exploration. The second workshop was about analysis and how to navigate trade-offs. Each of the 13 tasks (T1-T13) drew from various tools of systems thinking, dialogue, gaming, and scenarios: marked with coloured circles.

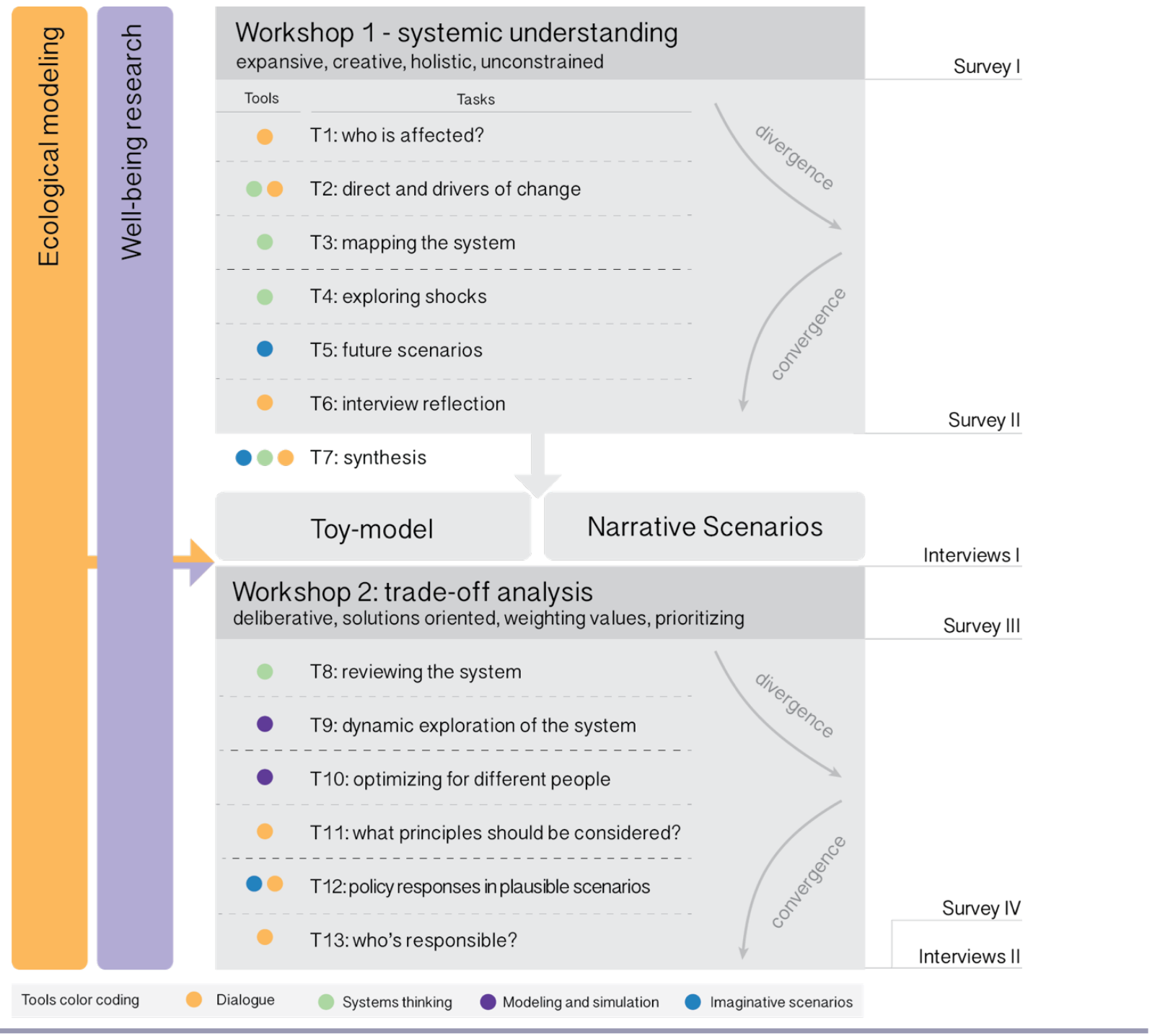

reserve, which is also managed by the Kenya Wildlife Service, but where fishing is allowed. Fishing is focused near shore and approximately half of the fishers use illegal beach seine nets widely perceived as destructive because their small meshes and the presumed habitat damage they cause. Nonbeach seine fishers use small gill nets, spearguns, traditional traps, and handlines individually or in small groups, catching somewhat larger and more valuable fishes. Catches are sold at the landing site to male and female fish traders. Male traders typically focus on more valuable and larger species and transport them by bicycle to higher value markets, whereas women fish vendors tend to specialize on smaller and cheaper fish, which they fry for retail to local communities. Historically, the fishery has been regulated by central government agencies, including the Kenya Fisheries Department and the Kenya Wildlife Services. Recent governmental efforts to devolve decision-making power at the local level have led to the implementation of beach management units (BMUs). Beach management units are responsible for coordinating fishing and market access, and BMU leaders are informally also involved in various community issues.

\section{Implementation of the knowledge coproduction process}

Process design

The coproduction process was composed of two workshops with a 6 month interval between them (Fig. 1). The first was aimed at generating an understanding of the system, the second to analyze trade-offs and deliberate about them (Fig. 1). Both workshops were conducted in Mombasa, Kenya and lasted for two consecutive days. To provide a multiplicity of interacting spaces and to support the appraisal and integration of multiple types of knowledge among the scientific group and participants, tools from systems thinking, dialogue, serious gaming, and scenarios 
were adapted. In brief, with dialogue tools, the conditions for sharing and for wide participation were created. Systems thinking brought attention to interrelations and broadening perspectives and simple models. Modeling and scenarios supported the exploration of system dynamics and future trajectories. For each of the two workshops, these tools were arranged in a way that the first day opened up a "divergence" in terms of views and knowledge, and the second day created "convergence" (Fig. 1). The workshops were integrative because insights from the ecological modeling of the coastal ecosystem and in-depth well-being research with primary stakeholders, those whose well-being is directly affected by the ecosystem, were woven together, in particular, in the cocreation of a toy-model and narrative scenarios during the second workshop (Fig. 1). A detailed description of workshop activities is available at http://tinyurl.com/pmowtickmanual.

\section{Participant selection}

The participants invited were secondary stakeholders, namely those whose well-being is not directly affected by the ecosystems, but who represent institutions and social groups that have some type of influence in coastal decision making and policy. A stakeholder analysis identified potential participants based on their importance and influence on the livelihoods of fisheries stakeholders (Brown et al. 2001). This was informed by literature on the case area and the expert knowledge of team members who had been working in the area for six or more years. The group was composed of local experts, NGO representatives, public administrators, policymakers, and community leaders (local fisherfolk representatives) in each workshop. The workshop activities explored trade-offs between broad systems objectives (e.g., food security, ecological status) and the well-being of various primary stakeholders, fisherfolk, and traders whose well-being is directly influenced by ecosystems. During the workshop five primary stakeholder groups were acknowledged (following Abunge et al. 2013 categories): female traders, male traders, beach seine crew, beach seine captain, and other fishers. They were analyzed separately because the mechanism through which they interact with one another and with the ecosystem differs and hence they might experience changes in social and ecological components in different ways. One community leader represented primary stakeholders in the workshops. Importantly however, detailed well-being research based on focus groups with each primary stakeholder group (published in Abunge et al. 2013) was brought into the workshops. Of the invited participants, 13 attended the first and 14 the second workshop, about $50 \%$ of those present in first workshop were also present in the second workshop.

\section{Workshop 1: systemic understanding}

The first workshop was about systems understanding, a phase of exploration of the system in which the scientific group supported participants in mapping causal relationships (Fig. 2) on the broader system and how they might influence the well-being of primary stakeholders (Fig. 1, T1-T3). Participants discussed how short and long term impacts, such as political unrest or climate change, would affect the possible future pathways of development (Fig. 1, T4-T5).

\section{Summarizing complexity}

Between the first and second workshop, the scientific team created two artifacts to synthesize what had been discussed thus far with regard to social-ecological dynamics (Fig. 1, T7). A flexible and simplified toy-model (Boschetti 2012) and a set of four storyline scenarios was used to collate various sources of data and insights from the first workshop and additional scientific research conducted within the overall project (Daw et al. 2015; detailed description in Appendix 1). Table 2 compares the two approaches. Further, results from other parts of the project were also summarized for presentation to participants, in particular, information on in-depth well-being research and ecological modeling results.

Fig. 2. Participants working on a system diagram during workshop 1.

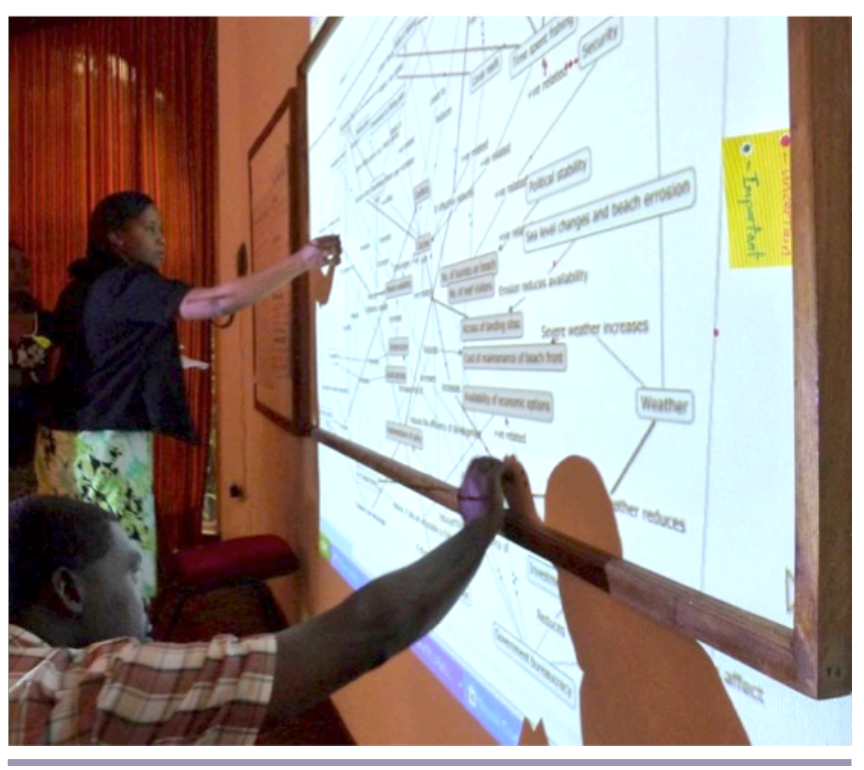

Table 2. Comparison of the toy-model and scenarios approach.

\begin{tabular}{ll}
\hline \hline Toy-model & Scenarios \\
\hline Quantitative & Qualitative \\
Animated - playable & Included feedbacks and agency \\
No transformation - relations & Holistic, no limit to number of \\
between variables remain same & variables \\
Complex drivers are lumped (e.g., & Drivers cause transformation \\
governance) & Drivers disaggregated into their \\
Strictly bounded, e.g., only reef & separate parts \\
ecosystem & Well-being implications tested with \\
Well-being implications assumed & stakeholders \\
based on simplistic relationships & No testing of causal logic or \\
Simulation allows testing of & assumptions \\
models of causality & \\
\hline
\end{tabular}

The toy-model brought together insights from well-being research, data from ecological modeling, and the systemic understanding created in workshop 1. The interactive toy-model was built in Microsoft Excel ${ }^{\circledR}$ (Fig. 3) using fuzzy logic rules to allow rapid modification and cocreation during the second workshop. The system diagram from workshop 1 was used to identify key social-ecological drivers. Ecological dynamics were driven by outputs from an ecological fisheries model using the Ecopath with Ecosim sofware built and parameterized for the specific case (Pauly et al. 2000). The toy-model dynamically represented how the five primary stakeholder groups' well-being (female traders, male traders, beach seine crew, beach seine 
Fig. 3. Toy-model interface in Microsoft Excel ${ }^{\circledR}$. The user can interact with the following parameters: Population, Governance, Economy, Tourism, and they can visualize how they dynamically affect fishing effort (beach seine effort and other effort), which in turn changes the ecological status and affect five different stakeholder groups in different ways. Also three management objectives (Profitability, Food, and Ecology) are shown. Detailed description in Appendix 1 and the Excel model is available at http://tinyurl. com/pmowtickmodel

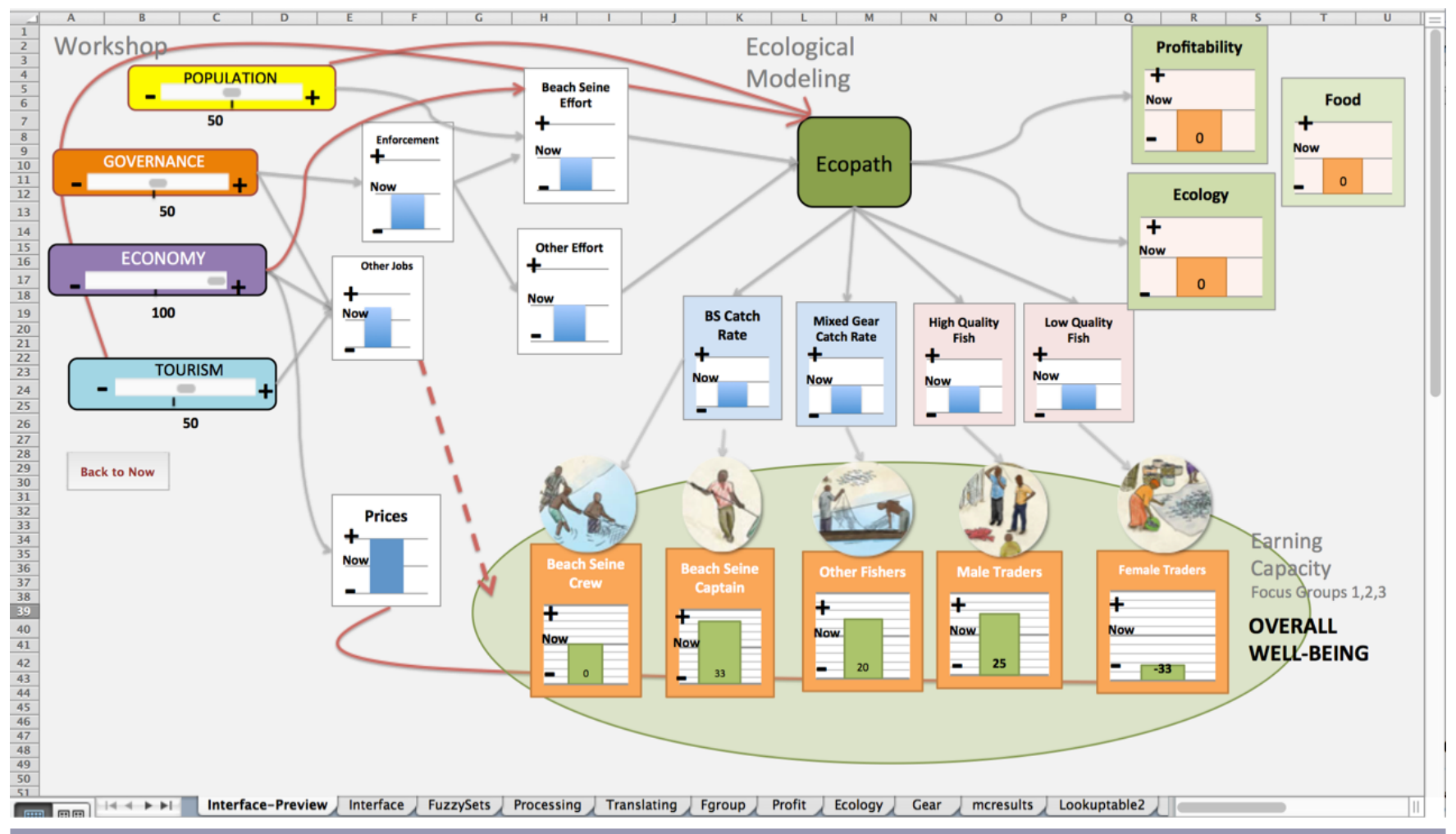

captain, and other fishers) were affected by changes in larger drivers, i.e., population, economy, governance, and tourism. The toy-model also provided dynamic output of system variables that corresponded to possible management objectives of the fishery, i.e., ecological status, profitability of the fisheries, and food security.

Four storylines of plausible futures of the coast were created (Appendix 1). These stories integrated secondary data on key indicator trends (e.g., population, fishing effort, economic development), system understanding (from first workshop), and ecological projections. The four stories were written by scientist groups with the support of local experts, and they were designed to incorporate the vast majority of systems components and dynamics that were discussed in the first workshop. Each story also featured potential trade-offs between primary stakeholders and systems objectives. These drafts were sent to local experts to verify the plausibility of the stories and to incorporate additional features. A graphic artist visually represented each story.

Workshop 2: trade-off analysis

In the second workshop, with the support of the toy-model and the scenarios, participants explored trade-off dynamics and deliberated about potential responses and interventions. This included an investigation of underlying values and the identification of important blockages and windows of opportunities for addressing trade-offs.
Research results from other parts of the project were presented to participants. Those included ecological modeling work that illustrates systems level trade-off dynamics. For example, maximizing the ecological system for economic profit would reduce the ecological status, whereas food security would remain stable. Results from primary stakeholders well-being research were also shared with participants.

Small groups of participants discussed each system relationship represented in the toy-model (Fig. 1, T8). This dialogue clarified model assumptions, and participants contributed adjustments that were implemented during the course of the workshop. Interacting with the model, participants explored the dynamics of trade-offs by attempting to maximize the well-being of different stakeholder groups (Fig. 1, T9). The model illustrated the dynamics of trade-offs and the difficulties for win-wins in this system. Finally, participants were informed about local community views on how each of the four future scenarios would affect them and how they would respond. Participants then discussed policy responses and responsibilities.

\section{Evaluation of the knowledge coproduction process}

Process observation were conducted and audio-video recordings were made during both workshops. Each workshop was also preceded and followed by a survey, and after each workshop an external consultant conducted a telephone interview with the scientific team and the majority of participants. Questions 
Table 3. Trade-offs present in the model. BSCr: beach seine crew well-being; BSCp: beach seine captain well-being; OF: other fishers well-being; MT: male traders well-being; FT: female traders well-being; Food: overall food security; Profit: overall profitability; Ecology: overall ecological integrity. Each column represents the optimization of one outcome variable of the toy-model (eight in total). Read by columns from to top to bottom. A star represents a variable that is being optimized in a given column. Arrows up represent a synergetic effect between a given pair of variables. Arrows down represent a trade-off. Sideways arrow represents no relationship. For example, in column 1, as we optimize for maximum beach seine crew well-being (BSCr), the well-being of "beach seine captain" increases while the well-being of "other fishers" (OF) decreases and so on.

\begin{tabular}{|c|c|c|c|c|c|c|c|c|}
\hline & 1. $\mathrm{BSCr}$ & 2. BSCp & 3. OF & 4. MT & 5. FT & 6. Food & 7. Profit & 8. Ecology \\
\hline $\mathrm{BSCr}$ & $*$ & $\rightarrow$ & $\nu$ & $\searrow$ & $\searrow$ & $\searrow$ & $\searrow$ & $\searrow$ \\
\hline BSCp & $\lambda$ & * & $\rightarrow$ & $\rightarrow$ & $\searrow$ & $\rightarrow$ & $\searrow$ & $\searrow$ \\
\hline OF & $\nu$ & $\nu$ & * & $\searrow$ & $\searrow$ & $\rightarrow$ & $\rightarrow$ & $\searrow$ \\
\hline MT & $\searrow$ & $\rightarrow$ & $\nearrow$ & $*$ & $\searrow$ & $\rightarrow$ & $\nearrow$ & $\searrow$ \\
\hline FT & $\rightarrow$ & $\nearrow$ & $\rightarrow$ & $\searrow$ & $*$ & $\nearrow$ & $\searrow$ & $\searrow$ \\
\hline Food & $\searrow$ & $\searrow$ & $\nu$ & T & $\searrow$ & * & $\rightarrow$ & $\pi$ \\
\hline Profit & $\nearrow$ & $\rightarrow$ & $\rightarrow$ & $\rightarrow$ & $\rightarrow$ & $\nearrow$ & * & $\rightarrow$ \\
\hline Ecology & $\nearrow$ & $\rightarrow$ & $\nearrow$ & $\nearrow$ & $\rightarrow$ & $\nearrow$ & $\nearrow$ & * \\
\hline
\end{tabular}

addressed participants' experience during the workshop, changes in their systemic understanding, and in their actions.

\section{RESULTS AND DISCUSSION}

\section{Coproduction of knowledge about trade-offs}

The knowledge coproduction process fostered the coproduction of knowledge about the system by bringing together scientific knowledge and tools with participants' practical and situated understandings of the system. Workshops participants represented a range of perspectives and agency within the system. Although participants came into the process with varying levels of understanding about existing or potential trade-offs, the knowledge coproduction space seemed to add a new dimension to these multiple understandings, as one participant said, the process "brought trade-offs to life." The process allowed this group of participants to see certain types of trade-offs (Box 1). The novelty of this work was the focus on social-ecological tradeoffs.

Next, we present evidence for how this process might have supported participants in addressing the challenges of perception and practice of trade-offs.

\section{Box 1:}

Trade-offs in the system

Various specific trade-offs were identified in the particular case study through the combination of various sources of data. Table 3 summarizes the specific trade-offs of the case study as defined in the toy-model used in workshop 2 to facilitate the engagement with trade-offs in a dynamic way. Daw et al. (2015) discussed specific trade-offs identified during the project.

A key trade-off that was not previously fully acknowledged was that between female traders and ecological integrity. Female traders' reliance on small fish, which they can sell in local markets, suggests that female traders' well-being increases when fishing effort increases, which may lead to a reduction in the overall ecological integrity and economic profitability of the resource.

Another trade-off highlighted in the model was between ecology and food production. In this multispecies system, high levels of fishing may lead to reduced ecological integrity but still support high levels of food production. This trade-off challenged the assumptions of some participants, who said that they presumed a positive relation between ecology and food production (Daw et al. 2015).

Developing a systemic perspective

One strategy to make invisible trade-offs visible is to develop a systemic understanding (Table 2). We found evidence that some participants developed an appreciation of the interdependences in the social-ecological system and others have strengthened the significance of particular connections that were previously given less priority.

[.. what] stood out the most [was] the interconnectivity that exists between say for example the resource and the economy and how this interconnectivity leads to tradeoffs. Participant interviews II.

Some participants increased their understanding of the many factors influencing the ecosystem and the well-being of users at the coast, and mostly attributed this to the system mapping exercise. For example, one typical response was:

I learnt how the [system] works and the drivers that influence the ecosystem, and I came to appreciate that there are many social factors that influence the ecosystem and how it is managed. Participant interviews II.

A new understanding of long-standing conflicts and social dynamics was expressed, as systemic interdependences became visible. One example was a conflict between conservation and beach seine fishing. The illegal fishing gear is deemed to be harmful to near shore ecosystems, and past efforts of enforcement have not been successful in stopping its utilization. One participant said:

For a long time we have not been able to stop beach seining in Nyali and this project has provided a means in which we can understand exactly what is going on in Nyali and why they just won't go away. Participant interviews II. 
The toy-model was particularly powerful in developing a dynamic understanding of trade-offs. The model was used as a device to communicate and experience how trade-offs emerge from complexity and interdependencies in the social-ecological system.

[..] playing with the toy-model helped me to understand it better [trade-offs]; more so when I was trying to optimize for beach seiners and how this was correlated to other jobs. Participant interviews II.

What really drove the idea of trade-offs home was the optimizing exercise [with the toy-model] because it enabled me to see the interconnectivity between factors and I could visualize how when one increased the other decreased. Participant interviews II.

\section{Seeing multiple perspectives}

In addition to learning about how trade-offs emerge from the complex interactions in the system, participants also expressed insights into how certain decisions would lead to trade-offs and how different people view these trade-offs. For example the tradeoff between female fish traders and male fish traders.

Trade-off exists between the mama karangas [female fish traders] and other fish traders - if we were to get rid of the small fish then the women would lose whilst the other traders may gain from the available large fish. Workshop 2, process observation.

During the workshop, participants were exposed to results of research on the well-being of primary stakeholders. This stimulated awareness of primary stakeholders' needs and perspectives. A participant reflected on this point:

There is a need of engaging with primary stakeholders, both in terms of getting them involved in the conversation, but also in knowing more about their needs and how interventions affect their livelihoods. Workshop 2, process observation.

\section{Reviewing narratives and assumptions}

Trade-offs can also be hidden by more socially attractive narratives that portray decisions as win-wins. One participant, while seeking to optimize the outputs of the toy-model for two primary stakeholders at the same time, faced the difficulties of achieving a positive result for both stakeholder groups.

Realization that there are hard decisions that have to be made and that we can't always have a win-win; trade-offs exist!

Powerful actors can at times make use of the narrative "hard decisions have to be made" as a moral justification for actions that might cause harm to the most vulnerable. Instead, in this context, it expressed an insight on the nature of trade-off dynamics in interdependent social-ecological systems and the need to engage with trade-offs rather than to immediately seek win-wins.

Although the toy-model was a simple representation of reality, it became a powerful tool for interfacing views from primary stakeholders, systems understanding from secondary stakeholders, as well as scientific knowledge about fisheries ecology. In this sense, the model was more than a stakeholder-scientist dualism. It created a conversation and questioned common narratives about certain system dynamics. The model required participants to engage with a quantitative representation of the system and challenged assumptions about some of the biophysical relationships within the system (Box 1). In one instance, in plenary, some participants questioned the ecological modelers about a particular dynamic in the toy-model resulting from the ecological modeling, whereby increasing fishing effort, the status of the ecology would diminish, but food security would increase. This dynamic clashed with the view that many participants had that ecological quality should be colinear with food production. A quote from the modeler scientist during the plenary session explains the dynamics revealed in the ecological model:
..even though big fish are gone - the situation can be quite stable. Big fish decreases means that small fish goes up. These small fishes can sustain a high rate of fishing. Workshop 2, process observation.

In another instance the toy-model exploration and discussions challenged the narrative that beach seine is the single gear degrading the ecological status. In the toy-model, increasing fishing effort by using other gear (other than beach seine) would have a large impact on the ecology because of the specific species and size catch that these other gears produce. One participant contrasted this ecological view by saying:

From the management perspective its wrong. [..] It is beach seining that is damaging the ecology-not the other fishers. Workshop 2, process observation.

Knowledge coproduction between scientists and local stakeholders implies a confrontation and integration of knowledge of participants and scientists. Although these examples show that the embodiment of ecological knowledge within the toy-model challenged participants' assumptions and narratives, the cocreation process also challenged and developed the assumptions of the research team. For example, the initial scope of the project was expanded as a result of the system mapping by stakeholders beyond those initially envisaged by the research team, to include technological advancement of the fishery, status of the Kenyan economy, aquaculture, and changes in governance because of the new Kenyan constitution. The importance of beach seine effort for female traders' well-being was also a challenge to conservation scientists' general view of the undesirability of this illegal gear.

\section{Conservation scientist: The realization of the challenge to incorporate the mama karangas perspective in our activities was really striking. We don't want to be the ones pushing them further down. Participant interviews II.}

Scenario exercises also led to a broader appreciation of potential impacts of certain decisions. For example, the narrative that future development of offshore fishing would lead to an overall increase in community well-being was present during both workshops. To some participants, the scenarios provoked a reflection on potential trade-offs that might emerge from such development. A participant commented: 
[..] I thought that by providing them with boats and vessels they will just go off shore, get lots of fish, sell it, have money and put food on the table. But I never saw it from the perspective of scenario $D$ which suggests that the program may not necessarily turn out all positive for the fishermen as we expect. This scenario opened my eyes to different possibilities of such a program. Participant interviews II.

\section{Putting insights into practice}

The majority of participants (11 out of 14) highlighted that the workshop would have an impact on their work activities. One participant reflected on how the "trade-off lenses" can be applied to their practice.

\begin{abstract}
For example when aiming for increased ecological biomass, instead of just concentrating on the number of those arrested for illegal fishing, as I am more aware of how increased regulations leads to less livelihoods from them, I will encourage for provision of alternative livelihoods for them as well. Participant interviews II.
\end{abstract}

This suggests that this participant was thinking beyond straightforward solutions to particular objectives, while at the same time proactively assessing how to mitigate harm for those groups that would lose out in response to decisions to which she/ he was responsible for. A majority also reported that the solutions discussed in the second workshop were relevant to their work. The practical relevance of a more holistic understanding of the system was reflected in participants' appreciation of the need for cross-sectorial collaborations.

In my organization we have various sectors dealing with natural resource management [..] and modeling assisted in showing the links between them. This can help in the harmonization of laws related to the various ecosystem services. Participant interviews I.

...previously I would avoid gender related meetings but after workshop I realized the inter linkages for management of the resource and I will seek to participate more in broader development issues. Participant interviews II.

Many reflected on how the notion of trade-off and interconnectivity had a direct affect on how they would perform their work.

I will have more awareness of trade-offs whilst working. For example in the case of marine protected areas, decisions are often made without taking into consideration the livelihoods of the fishermen and they do not get any compensation after these decisions are made. Participant interviews II.

Either in interaction with the toy-model or while considering trade-off dynamics in the scenarios, we observed that participants, when faced with a trade-off, say for instance between the wellbeing of female traders and male traders, were more likely to offer ideas about how to transform the dynamics rather than confront the hard choices of trade-offs. For example, some suggested intervening in the trading system to allow women to access fish, or to improve the ability of those doing beach seining to benefit from other jobs created in the economy. This might support the insights from social dilemmas literature that suggests that tradeoffs are unconformable and difficult to engage with from a cognitive-emotional perspective. But also, it suggests that making trade-offs explicit might lead to novel ideas of practical interventions that move the particular aspect of the system beyond trade-offs.

Developing a collaborative approach

The process promoted changes in participants' interpersonal relationships and in organizational relationships. Participants expressed an appreciation of the opportunity to interact and develop ideas of potential collaborations with other participants and institutions. The contribution of the encounters to the development of new networks was limited (nine participants already knew or had worked with each other prior to this workshop), but participants expressed that the opportunity to meet others in this somewhat unconventional context reinforced working relationships, developed trust, and created awareness about the perspectives of other participants.

We also observed evidence of learning that might have an impact at the organizational level. When asked about the relevance in their work, a common response was that they would now have to take primary stakeholders' well-being into consideration when pursuing conservation interventions.

Previously I was unaware of the existence of BMUs, though I have to say it sounds like they are not well organized. I think if [participant's organization] was to start a marine department, I would definitely suggest that we get involved in improving the BMUs. Participant interviews II.

It (the workshop) gave me a better understanding of how other organizations view these issues and how they prioritize efforts in their work which is useful as previously I had not had the chance to sit with other professionals to discuss how they work. Participant interviews II.

Reflecting on systemic goals

The knowledge coproduction also brought awareness to systems level trade-offs, i.e., trade-offs that emerge depending on the different management objectives for ecosystems. In the toymodel, resource profitability, ecosystem quality, or food security were represented as systems-level objectives. The process supported the identification of trade-offs within these objectives and also the acknowledgement of trade-offs between the system level and the well-being of primary stakeholders. While exploring these trade-offs, participants were able to reflect on what goals are being pursued for the system and the types of trade-offs that might emerge from this.

We report on evidence of changes in participants' understanding and actions within the time frame of the project. To further understand the effects of the process in practice would require investigating how new insights might be brought into participants routines over a longer period, how they disseminate to peers and communities, and how organizational and institutional features 
may inhibit the ability of participants to put new understandings into practice, e.g., deterrent incentive structures, time pressures within their institutions, or power struggles. However, based on what has been observed, we can speculate that a trade-off lens for the management of social-ecological systems may catalyze innovative thinking and solutions in relation to policy interventions.

\section{Reflections on the participatory process}

We have discussed how knowledge coproduction can be a strategy to address the challenge of dealing with trade-offs. Learning is certainly not equal for everyone. People come to the process with various levels of understanding and thinking skills (CookGreuter 2000). The high diversity of tools and communication configurations increases the chance of every participant being heard in one way or another (Barnaud and Van Paassen 2013). In particular, the subgroup discussions, which were followed by the expression of more individual opinions, e.g., voting, writing post-its, speaking in plenary, were designed to stimulate the participants' reflections and to make them more confident about sharing them. It also stimulated participants to engage in the discussion from their individual as well as institutional perspectives.

\section{Difficulties in assessing learning}

In assessing learning in knowledge coproduction, it is challenging to disentangle whether the outcomes of the process are attributed to a particular tool or to the way in which facilitation was performed (Heylings and Bravo 2007). We have discussed the evidence we found based on interviews and process observation, suggesting that this process led to learning that is relevant to addressing social-ecological trade-offs. However, we acknowledge our limited understanding of all the possible learning that may have taken place (or was hindered) in this process. Other challenges in assessing learning include that our data (process observation and recall interviews) may be affected by participant memories, self-assessment, and a bias toward positive reporting of learning, even though interviews were conducted by a consultant not involved in running the workshop. These challenges are likely to emerge in processes similar to this, given constraints under which such processes operate. To attend to the repeated calls within knowledge coproduction literature for more empirical observations of learning outcomes (Fazey et al. 2013), it seems desirable to bring into the coproduction process explicit questions of learning and to explore with participants what are the desirable learning outcomes and what sets of indicators can be designed to evaluate the development toward learning goals.

\section{Ownership and legitimacy}

In participatory modeling, ensuring legitimacy is key but it can be difficult to achieve. The literature on participatory modeling emphasizes the following principles (Barreteau et al. 2013): transparency of the modelers' assumptions and flexible adaptation of the model to integrate the participants' suggestions. A key moment that enhanced the ownership was during the second workshop when participants were invited to suggest structural changes to the toy-model. A certain balance needed to be attained to enable the participants to have sufficient confidence in exploring the model dynamics, i.e., trade-off analysis, while at the same time not over complicating the system in a manner that would lead to confusion. The fact that the model was flexible and was adjusted during the workshop increased the level of transparency and legitimacy. The first attempt to explore the model with participants led to resistance toward the model, because there was not enough ownership. Even after revision, some participants still questioned the validity of the underlying data and still referred to the model as "your [the scientists] model." The following statement however demonstrates the importance of reviewing the model to ensure its applicability.

The process was inclusive because our suggestions and corrections to the model were incorporated; at the same time this helped us realize that models can have errors and they are not perfect, but they are still useful and we were able to see its usefulness. Participant interviews II.

Lessons from past experiments in the field of participatory modeling mention the importance of having numerous iterations between the model and the participants (Barreteau et al. 2013). The participants' ownership would probably have increased with a longer participatory process, with more than two workshops, but this is obviously very costly (scientists face their own tradeoffs). Besides, the posture of the scientists is also a crucial element. Perhaps in this case, given the fact that the scientists modelers were already knowledgeable about the system, there was a great reluctance to challenge their own basic assumptions about the system. Researchers developing the companion modeling approach suggest that for this reason, it can be useful to have a team in which the modeler and the specialist are two separate people (Etienne 2011).

What is the role of modeling and scenarios?

The use of the coconstructed model in the first workshop allowed stakeholders to externalize their mental models, to have dialogue, to align with others, and to feel ownership of the product. Meanwhile, the toy-model used in the second workshop gave the possibility of interacting with a simplified but animated model, which drew both from the coconstructed model as well as from ecosystem dynamics of fisheries ecology. This model allowed a semiquantitative exploration of trade-offs. Reed et al. (2013) claimed that simple models, because of the amount of resources and difficulties in calibration, have a limited benefit in informing scenarios in comparison to what secondary data and local knowledge can provide. However, we used toy-models to integrate secondary data and local knowledge with available scientific data and observed that participant's interaction with this model was a key factor for the acquisition of a tacit and dynamic understanding of the trade-offs concept. With the experience that the model created, participants were able to apply the heuristic to other situations during the conversations. Several researchers using gaming tools have made similar observations. Gaming is known to stimulate experiential learning, i.e., the participants learn by observing the effects of their choices or actions on the other elements of the system (Kolb 1984, Mathevet et al. 2007). Gaming is therefore considered to be a suitable mode of communication to convey complexity because it allows multiple participants to interactively examine the complex systems that they are part of (Duke 1974, Barnaud et al. 2007).We acknowledge that sophisticated models may at times lead to disenfranchisement of some participants and that the development of an embodied experience of a concept, such as trade-offs, can be achieved with less sophisticated models (Newell 2012). 
Although the model was introduced as a thinking tool to support the collective process, some participants held to the idea of the model as a tool for prediction. Perhaps due to perceptions of scientific expertise, a number of stakeholders thought of the toymodel as a predictive tool in which data could be inserted and used to tell something about how policies would play out. Although questioning the uses of models and how they relate to reality is an important aspect of developing complexity thinking and sophisticated epistemological beliefs (Barreteau et al. 2003, Fazey 2010), it is important for scientists to frame the use of models very precisely from the very beginning of the interactions. Building toy-models for heuristic thinking in a participatory way is best seen as a journey that progressively leaves the models behind, while remaining with the insights that they may stimulate.

Much like the interactive toy-model, the artistic representation of scenarios have been used flexibly in different contexts to engage with participants and explore the impacts of these stories, stakeholder agency, and windows of opportunity for action. Scenarios contrasted and complemented the toy-model activity incorporating aspects beyond the scope of the toy-model. For instance, no feedback was included in the toy-model, in the sense that stakeholders were not modeled to change their actions or strategies in response to ecological or well-being changes. Scenarios helped to explore the agency of stakeholders and decision makers within the system, how they may respond in different scenarios, and to identify points of leverage for policy to mitigate or change the nature of trade-offs that were hard-wired into the model. A similar research strand utilizes agent-based models as toy-models for collective learning in social-ecological systems. In that line of work, agent-based models, which normally include feedback between social behavior and ecological change, are used to explore various scenarios and trade-offs (Bousquet et al. 2007). However, different types of scenarios (artistic representations versus computer simulation) are likely to have different cognitive and learning effects that would be interesting to investigate further.

\section{CONCLUSION}

Trade-offs result from complex social-ecological interactions that can be difficult to perceive. Putting the insights of trade-offs into practice can also present various challenges. We have explored how knowledge coproduction can be a mechanism for tackling these challenges and to develop individual and collective capacities to address social-ecological trade-offs. We explored learning dimensions of an iterative participatory process in coastal Kenya, aimed at instigating trade-off thinking among governance actors.

Trade-offs can be invisible because of a lack of systemic understanding. Trade-offs are seen differently from different perspectives and they can be hidden by assumptions and narratives. We observed evidence that, the combination of systems thinking, participatory modeling, and interactive exploration of dynamics of trade-offs in toy-model and scenarios, led to an appreciation of systemic interdependences and the dynamic nature of trade-offs. In this sense, the process of knowledge coproduction in a multiactor setting led to a trade-off analysis that was highly understandable for participants even with the use of simple toy-models and narrative scenarios.
In interacting with the model, participants demonstrated the development of trade-off lenses, a thinking heuristic that could be applied to various aspects of the system, even those that were not explicitly represented in the toy-model. This has may have led participants to develop novel thinking about ways to make decisions in the face of trade-offs while catering to those that lose out. Also, participants developed ideas of how to transform dynamics in the system that would eliminate the need for tradeoffs in the first place.

Given the indications of learning observed in this case, we propose that knowledge coproduction processes may be a promising contribution to developing strategies that address trade-offs. Further research needs include to better understand the way in which insights from knowledge coproduction can permeate and influence management and policy-making, broader social narratives, and how it may influence organizational and institutional change. We found some evidence of the development of trust and relationships that could form the basis for such changes in practice. However, even if coproduction processes can enhance learning and relationships, they may be useful but insufficient in situations in which trade-offs are complicated by deep-rooted conflicts of interest or extreme inequality or marginalization of certain stakeholders. Thus, the extent to which these types of unconventional spaces may affect power dynamics is also an important future avenue of research that is decisive for how trade-offs are addressed.

Addressing trade-offs may involve compromises and choices, which are often hard and controversial (as detailed in Daw et al. 2015). Addressing trade-offs is a fundamental aspect of the search for equitable and sustainable futures. To consider trade-offs means acknowledging the interdependencies of multiple goals and values and to acknowledge that win-win solutions are difficult to create. Developing capacities to perceive and address trade-offs are essential in an increasingly intertwined planet.

Responses to this article can be read online at: http://www.ecologyandsociety.org/issues/responses. $\mathrm{php} / 8920$

\section{Acknowledgments:}

The primary and secondary stakeholders of the Nyali Beach fishery in focus groups and workshops is gratefully acknowledged. Arthur Tuda, Sheila Heymans, Allister McGregor, and Raphaël Mathevet advised on the design of the project. This paper is a result of the project "Participatory Modelling Frameworks to Understand Wellbeing Trade-offs in Coastal Ecosystem Services" (P-mowtick) funded by the Ecosystem Services and Poverty Alleviation (ESPA) program (ref number: NE/I00324X/1) and received further support from K. Brown's ESRC Professorial Fellowship (RES-051-27-0263). The ESPA program is funded by the Department for International Development (DFID), the Economic and Social Research Council (ESRC), and the Natural Environment Research Council (NERC). Diego Galafassi also acknowledges the support of the Strategic Research Program EkoKlim at Stockholm University through the Swedish Research Council for Environment, Agricultural Sciences and Spatial Planning (FORMAS). 


\section{LITERATURE CITED}

Abunge, C., S. Coulthard, and T. M. Daw. 2013. Connecting marine ecosystem services to human well-being: insights from participatory well-being assessment in Kenya. Ambio 42 (8):1010-1021. http://dx.doi.org/10.1007/s13280-013-0456-9

Argyris, C. 1976. Single-loop and double-loop models in research on decision making. Administrative Science Quarterly 21 (3):363-375. http://dx.doi.org/10.2307/2391848

Axelrod, R., and M. D. Cohen. 2000. Harnessing complexity: organizational implications of a scientific frontier. Basic Books, New York, New York, USA.

Barnaud, C., T. Promburom, G. Trébuil, and F. Bousquet. 2007. An evolving simulation/gaming process to facilitate adaptive watershed management in northern mountainous Thailand. Simulation and Gaming 38(3):398-420. http://dx.doi. org/10.1177/1046878107300670

Barnaud, C., and A. Van Paassen. 2013. Equity, power games, and legitimacy: dilemmas of participatory natural resource management. Ecology and Society 18(2):21. http://dx.doi. org/10.5751/es-05459-180221

Barreteau, O., M. Antona, P. d'Aquino, S. Aubert, S. Boissau, F. Bousquet, W. Daré, M. Etienne, C. Le Page, R. Mathevet, and G. Trébuil. 2003. Our companion modelling approach. Journal of Artificial Societies and Social Simulation 6(2):1. [online] URL: http://jasss.soc.surrey.ac.uk/6/2/1.html

Barreteau, O., P. Bots, K. Daniell, M. Etienne, P. Perez, C. Barnaud, D. Bazile, N. Becu, J.-C. Castella, W. S. Daré, and G. Trébuil. 2013. Participatory approaches. Pages 197-234 in B. Edmonds and R. Meyer, editors. Simulating social complexity: a handbook. Springer, Berlin, Germany. http://dx.doi. org/10.1007/978-3-540-93813-2_10

Barreteau, O., and F. Bousquet. 2001. Role-playing games for opening the black box of multi-agent systems: method and lessons of its application to Senegal River Valley irrigated systems. Journal of Artificial Societies and Social Simulation 4(2):5. [online] URL: http://jasss.soc.surrey.ac.uk/4/2/5.html

Berkes, F., C. Folke, and J. Colding. 2000. Linking social and ecological systems: management practices and social mechanisms for building resilience. Cambridge University Press, Cambridge, UK.

Bohm, D. 1996. On dialogue. Routledge, New York, New York, USA.

Boschetti, F. 2012. A computational model of a mental model used to reason about climate change. Environmental Science and Policy 15(1):125-135. http://dx.doi.org/10.1016/j.envsci.2011.09.006

Bousquet, F., J.-C. Castella, G. Trébuil, C. Barnaud, S. Boissau, and S. P. Kam. 2007. Using multi-agent systems in a companion modelling approach for agroecosystem management in SouthEast Asia. Outlook on Agriculture 36(1):57-62. http://dx.doi. org/10.5367/000000007780223650

Brown, K., W. N. Adger, E. Tompkins, P. Bacon, D. Shim, and K. Young. 2001. Trade-off analysis for marine protected area management. Ecological Economics 37(3):417-434. http://dx.doi. org/10.1016/s0921-8009(00)00293-7
Carpenter, S. R., H. Mooney, J. Agard, D. Capistrano, R. S. Defries, S. Diaz, T. Dietz, A. K. Duraiappah, A. Oteng-Yeboah, H. M. Pereira, C. Perrings, W. V. Reid, J. Sarukhan, R. J. Scholes, and A. Whyte. 2009. Science for managing ecosystem services: beyond the Millennium Ecosystem Assessment. Proceedings of the National Academy of Sciences 106(5):1305-1312. http://dx. doi.org/10.1073/pnas.0808772106

Cash, D. W., W. C. Clark, F. Alcock, N. M. Dickson, N. Eckley, D. H. Guston, J. Jäger, and R. B. Mitchell. 2003. Knowledge systems for sustainable development. Proceedings of the National Academy of Sciences 100(14):8086-8091. http://dx.doi.org/10.1073/ pnas. 1231332100

Cook-Greuter, S. R. 2000. Mature ego development: a gateway to ego transcendence? Journal of Adult Development 7:227-240. http://dx.doi.org/10.1023/A:1009511411421

Coulthard, S., D. Johnson, and J. A. McGregor. 2011. Poverty, sustainability and human wellbeing: a social wellbeing approach to the global fisheries crisis. Global Environmental Change 21 (2):453-463. http://dx.doi.org/10.1016/j.gloenvcha.2011.01.003

Daré, W., A. Van Paassen, R. Ducrot, R. Mathevet, J. Queste, G. Trébuil, C. Barnaud, and E. Lagabrielle. 2013. Learning about interdependencies and dynamics. Pages 233-262 in M. Etienne, editor. Companion modelling: a participatory approach to support sustainable development. Springer, Dordrecht, The Netherlands. http://dx.doi.org/10.1007/978-94-017-8557-0 10

Daw, T., K. Brown, S. Rosendo, and R. Pomeroy. 2011. Applying the ecosystem services concept to poverty alleviation: the need to disaggregate human well-being. Environmental Conservation 38 (4):370-379. http://dx.doi.org/10.1017/s0376892911000506

Daw, T. M., S. Coulthard, W. W. L. Cheung, K. Brown, C. Abunge, D. Galafassi, G. D. Peterson, T. R. McClanahan, J. O. Omukoto, and L. Munyi. 2015. Evaluating taboo trade-offs in ecosystems services and human well-being. Proceedings of the National Academy of Sciences 112(22):6949-6954. http://dx.doi. org/10.1073/pnas.1414900112

Duke, R. D. 1974. Gaming: the future's language. Sage, Thousand Oaks, California, USA. [online] URL: http://www.isaga.com/ index.php/about-sag/gaming-the-futures-language

Etienne, M. 2011. Companion modelling: a participatory approach to support sustainable development. Editions Quae, Versailles, France.

Etienne, M., D. R. Du Toit, and A. S. Pollard. 2011. ARDI: a coconstruction method for participatory modeling in natural resources management. Ecology and Society 16(1):44. [online] URL: http://www.ecologyandsociety.org/vol16/iss1/art44/ http:// dx.doi.org/10.5751/es-03748-160144

Fazey, I. 2010. Resilience and higher order thinking. Ecology and Society 15(3):9. [online] URL: http://www.ecologyandsociety. org/vol15/iss $3 /$ art9/

Fazey, I., A. C. Evely, M. S. Reed, L. C. Stringer, J. Kruijsen, P. C. L. White, A. Newsham, L. Jin, M. Cortazzi, J. Phillipson, K. Blackstock, N. Entwistle, W. Sheate, F. Armstrong, C. Blackmore, J. Fazey, J. Ingram, J. Gregson, P. Lowe, S. Morton, and C. Trevitt. 2013. Knowledge exchange: a review and research agenda for 
environmental management. Environmental Conservation 40 (1):19-36. http://dx.doi.org/10.1017/s037689291200029x

Fazey, I., N. Pettorelli, J. Kenter, D. Wagatora, and D. Schuett. 2011. Maladaptive trajectories of change in Makira, Solomon Islands. Global Environmental Change 21(4):1275-1289. http://dx. doi.org/10.1016/j.gloenvcha.2011.07.006

Goldstein, J. H., G. Caldarone, T. K. Duarte, D. Ennaanay, N. Hannahs, G. Mendoza, S. Polasky, S. Wolny, and G. C. Daily. 2012. Integrating ecosystem-service trade-offs into land-use decisions. Proceedings of the National Academy of Sciences 109 (19):7565-7570. http://dx.doi.org/10.1073/pnas.1201040109

Habermas, J. 1984. The theory of communicative action: reason and the rationalization of society. Volume I. Beacon, Boston, Massachusetts, USA.

Heylings, P., and M. Bravo. 2007. Evaluating governance: a process for understanding how co-management is functioning, and why, in the Galapagos Marine Reserve. Ocean and Coastal Management 50(3-4):174-208. http://dx.doi.org/10.1016/j. ocecoaman.2006.09.003

Howe, C., H. Suich, B. Vira, and G. M. Mace. 2014. Creating winwins from trade-offs? Ecosystem services for human well-being: a meta-analysis of ecosystem service trade-offs and synergies in the real world. Global Environmental Change 28:263-275. http:// dx.doi.org/10.1016/j.gloenvcha.2014.07.005

Höijer, B., R. Lidskog, and Y. Uggla. 2006. Facing dilemmas: sense-making and decision-making in late modernity. Futures 38 (3):350-366. http://dx.doi.org/10.1016/j.futures.2005.07.007

Ison, R., C. Blackmore, and B. L. Iaquinto. 2013. Towards systemic and adaptive governance: exploring the revealing and concealing aspects of contemporary social-learning metaphors. Ecological Economics 87:34-42. http://dx.doi.org/10.1016/j. ecolecon.2012.12.016

Kenter, J. O., L. O';Brien, N. Hockley, N. Ravenscroft, I. Fazey, K. N. Irvine, M. S. Reed, M. Christie, E. Brady, R. Bryce, A. Church, N. Cooper, A. Davies, A. Evely, M. Everard, R. Fish, J. A. Fisher, N. Jobstvogt, C. Molloy, J. Orchard-Webb, S. Ranger, M. Ryan, V. Watson, and S. Williams. 2015. What are shared and social values of ecosystems? Ecological Economics 111:86-99. http://dx.doi.org/10.1016/j.ecolecon.2015.01.006

Kolb, D. A. 1984. Experiential learning: experience as the source of learning and development. Prentice Hall, Englewood Cliffs, New Jersey, USA

Lankford, B., and D. Watson. 2007. Metaphor in natural resource gaming: insights from the River Basin game. Simulation and Gaming 38(3):421-442. http://dx.doi.org/10.1177/1046878107300671

Lele, S., and V. Srinivasan. 2013. Disaggregated economic impact analysis incorporating ecological and social trade-offs and techno-institutional context: a case from the Western Ghats of India. Ecological Economics 91:98-112. http://dx.doi.org/10.1016/ j.ecolecon.2013.03.023

Mathevet, R., C. Le Page, M. Etienne, G. Lefebvre, B. Poulin, G. Gigot, S. Proréol, and A. Mauchamp. 2007. BUTORSTAR: a role-playing game for collective awareness of wise reedbed use. Simulation and Gaming 38(2):233-262. http://dx.doi. org/10.1177/1046878107300665
McClanahan, T. R. 2010. Effects of fisheries closures and gear restrictions on fishing income in a Kenyan coral reef. Conservation Biology 24(6):1519-1528. http://dx.doi.org/10.1111/j.1523-1739.2010.01530. $\underline{\mathrm{X}}$

McClanahan, T. R., and S. Mangi. 2001. The effect of a closed area and beach seine exclusion on coral reef fish catches. Fisheries Management and Ecology 8:107-121. http://dx.doi.org/10.1046/ j.1365-2400.2001.00239.x

McShane, T. O., P. D. Hirsch, T. C. Trung, A. N. Songorwa, A. Kinzig, B. Monteferri, D. Mutekanga, H. V. Thang, J. L Dammert, M. Pulgar-Vidal, M. Welch-Devine, J. P. Brosius, P. Coppolillo, and S. O'Connor. 2011. Hard choices: making tradeoffs between biodiversity conservation and human well-being. Biological Conservation 144(3):966-972. http://dx.doi.org/10.1016/ j.biocon.2010.04.038

Meadows, D. H. 2008. Thinking in systems: a primer. Chelsea Green, White River Junction, Vermont, USA.

Muradian, R., M. Arsel, L. Pellegrini, F. Adaman, B. Aguilar, B. Agarwal, E. Corbera, D. E. de Blas, J. Farley, G. Froger, E. GarciaFrapolli, E. Gómez-Baggethun, J. Gowdy, N. Kosoy, J. F. Le Coq, P. Leroy, P. May, P. Méral, P. Mibielli, R. Norgaard, B. Ozkaynak, U. Pascual, W. Pengue, M. Perez, D. Pesche, R. Pirard, J. RamosMartin, L. Rival, F. Saenz, G. Van Hecken, A. Vatn, B. Vira, and K. Urama. 2013. Payments for ecosystem services and the fatal attraction of win-win solutions. Conservation Letters 6 (4):274-279. http://dx.doi.org/10.1111/j.1755-263x.2012.00309.x

Muro, M. and P. Jeffrey. 2008. A critical review of the theory and application of social learning in participatory natural resource management processes. Journal of Environmental Planning and Management 51(3):325-344. http://dx.doi.org/10.1080/09640560$\underline{801977190}$

Newell, B. 2012. Simple models, powerful ideas: towards effective integrative practice. Global Environmental Change 22(3):776-783. http://dx.doi.org/10.1016/j.gloenvcha.2012.03.006

Pauly, D., V. Christensen, and C. Walters. 2000. Ecopath, Ecosim, and Ecospace as tools for evaluating ecosystem impact of fisheries. ICES Journal of Marine Science 57(3):697-706. http:// dx.doi.org/10.1006/jmsc. 2000.0726

Peterson, G. D., G. S. Cumming, and S. R. Carpenter. 2003. Scenario planning, a tool for conservation in an uncertain world. Conservation Ecology 17:358-366. http://dx.doi.org/10.1046/ j.1523-1739.2003.01491.x

Raudsepp-Hearne, C., G. D. Peterson, and E. M. Bennett. 2010. Ecosystem service bundles for analyzing trade-offs in diverse landscapes. Proceedings of the National Academy of Sciences 107 (11):5242-5247. http://dx.doi.org/10.1073/pnas.0907284107

Reed, M. S., A. C. Evely, G. Cundill, I. Fazey, J. Glass, A. Laing, J. Newig, B. Parrish, C. Prell, C. Raymond, and L. C. Stringer. 2010. What is social learning? Ecology and Society 5(4):r1. [online] URL: http://www.ecologyandsociety.org/vol15/iss4/resp1/

Reed, M. S., J. Kenter, A. Bonn, K. Broad, T. P. Burt, I. R. Fazey, E. D. G. Fraser, K. Hubacek, D. Nainggolan, C. H. Quinn, L. C. Stringer, and F. Ravera. 2013. Participatory scenario development for environmental management: a methodological framework 
illustrated with experience from the UK uplands. Journal of Environmental Management 128:345-362. http://dx.doi.org/10.1016/ j.jenvman.2013.05.016

Reyers, B., J. L. Nel, P. J. O’Farrell, N. Sitas, and D. C. Nel. 2015. Navigating complexity through knowledge co-production: mainstreaming ecosystem services into disaster risk reduction. Proceedings of the National Academy of Sciences 112 (24):7362-7368. http://dx.doi.org/10.1073/pnas.1414374112

Rittel, H. W. J., and M. M. Webber. 1973. Dilemmas in a general theory of planning. Policy Sciences 4(2):155-169. http://dx.doi. org/10.1007/bf01405730

Rodríguez, J. P., T. D. Beard, Jr., E. M. Bennett, G. S. Cumming, S. J. Cork, J. Agard, A. P. Dobson, and G. D. Peterson. 2006. Trade-offs across space, time, and ecosystem services. Ecology and Society 11(1):28. [online] URL: http://www.ecologyandsociety. org/vol11/iss1/art28/ http://dx.doi.org/10.5751/es-01667-110128

Schoemaker, P. J. H., and P. E. Tetlock. 2012. Taboo scenarios: how to think about the unthinkable. California Management Review 54(2):5-24.

Stave, K. A. 2002. Using system dynamics to improve public participation in environmental decisions. System Dynamics Review 18(2):139-167. http://dx.doi.org/10.1002/sdr.237

Sterman, J. D. 1994. Learning in and about complex systems. System Dynamics Review 10(2-3):291-330. http://dx.doi. org/10.1002/sdr.4260100214

Tàbara, J. D., and I. Chabay. 2013. Coupling human information and knowledge systems with social-ecological systems change: reframing research, education, and policy for sustainability. Environmental Science and Policy 28:71-81. http://dx.doi. org/10.1016/j.envsci.2012.11.005

Tengö, M., E. S. Brondizio, T. Elmqvist, P. Malmer, and M. Spierenburg. 2014. Connecting diverse knowledge systems for enhanced ecosystem governance: the multiple evidence base approach. Ambio 43(5):579-591. http://dx.doi.org/10.1007/ $\underline{\text { s13280-014-0501-3 }}$

Tetlock, P. E. 2003. Thinking the unthinkable: sacred values and taboo cognitions. Trends in Cognitive Sciences 7(7):320-324. http://dx.doi.org/10.1016/s1364-6613(03)00135-9

Walker, B., and D. Salt. 2012. Resilience practice: building capacity to absorb disturbance and maintain function. Island, Washington, D.C., USA. http://dx.doi.org/10.5822/978-1-61091-231-0 


\section{Table of Contents}

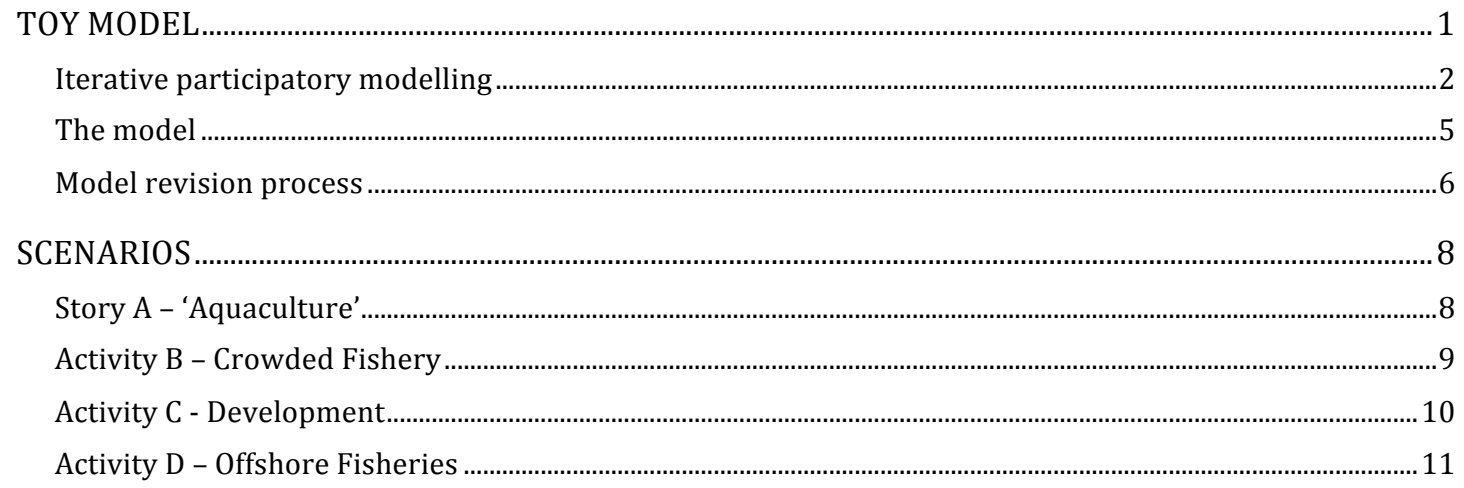

\section{TOY MODEL}

This appendix provides further information on the toy-model and scenarios that was utilized to explore social-ecological tradeoffs in coastal Kenya.

Figure $\mathrm{S} 1$ is a system diagram of the variables and the connections of the toy-model utilized by participants to explore social-ecological tradeoffs. This particular version of the model emerged through a series of iterations and previous versions co-constructed with participants of the workshops referred to in the main paper. We summarize here the participatory process of model building.

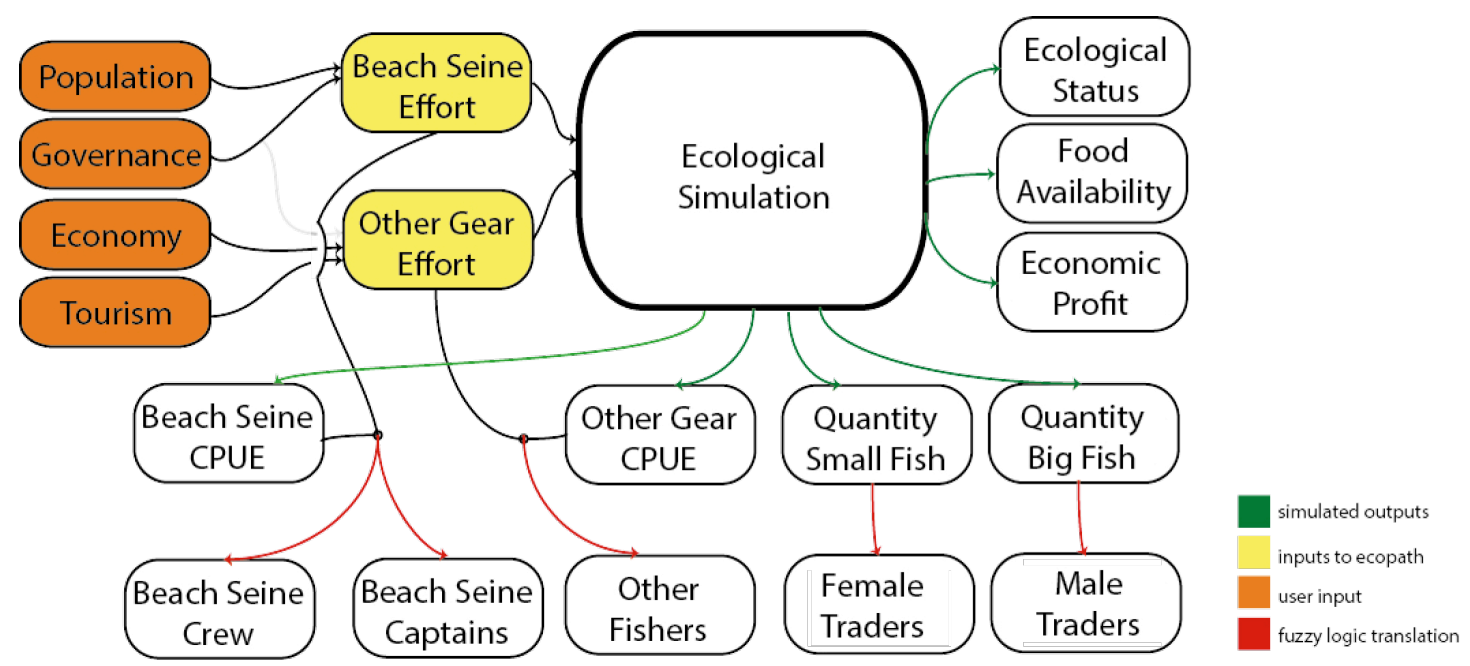

Figure S1. Final structure (after stakeholder's revisions) of the toy-model used to tradeoff analysis exercise. 


\section{Iterative participatory modelling}

During the first workshop, through dialogue and discussions, participants developed a collective mental model of the social-ecological system in focus. Figure S2 is the direct transcription of this map that was created using post-its and drawings of arrows on a wall. A degree of uncertainty and a degree of overall importance was attributed to each linkage. These attributes were useful for the analysis and further "simplification" of the model.

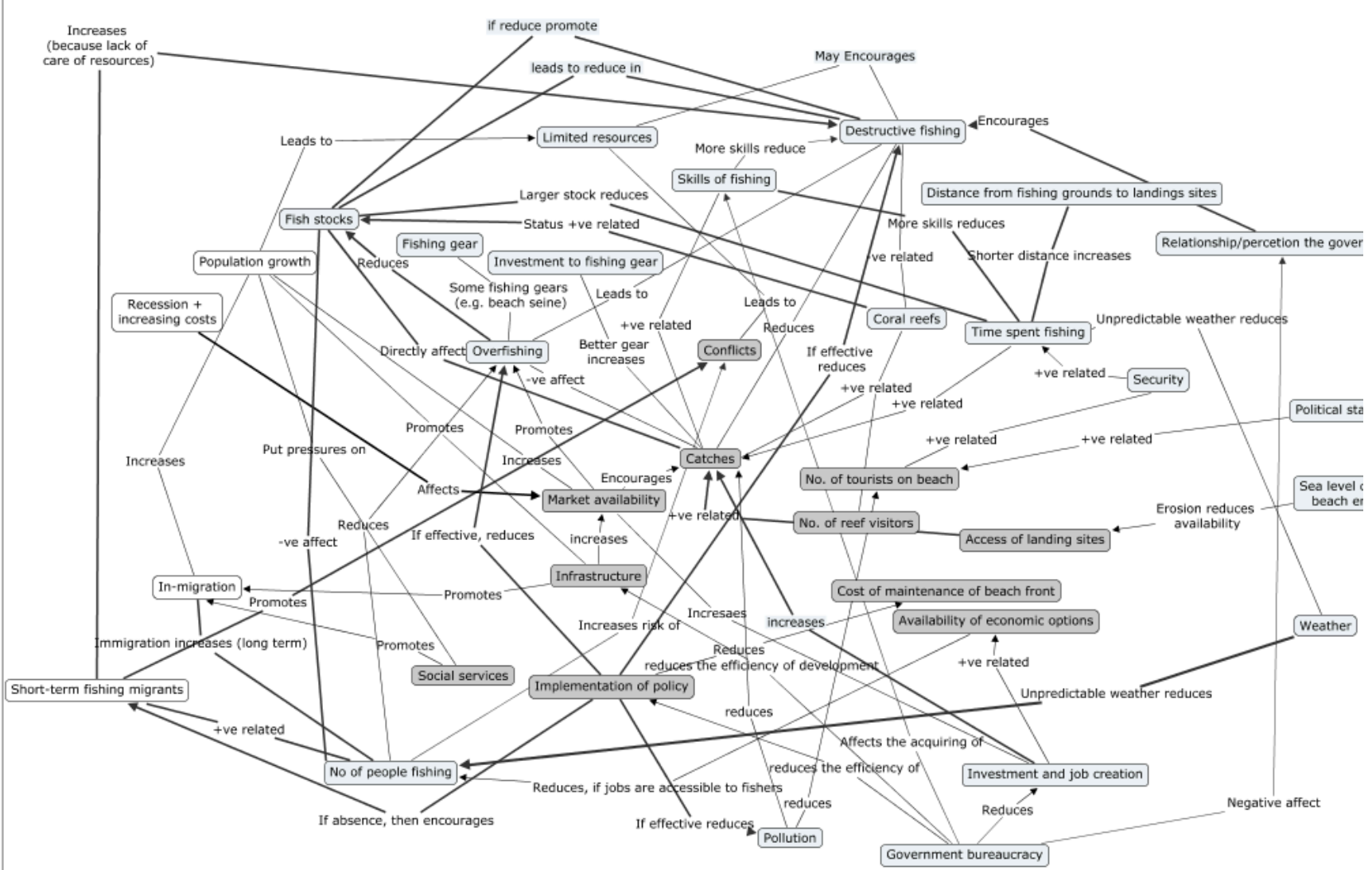

Figure S2. Workshop 1 collective model

In order to explore social-ecological tradeoffs the challenge now was to link this collective model (built by secondary stakeholders, i.e. those whose wellbeing is not directly affected by changes in ecosystems but that have influence in policy and management), to a ecological model of the fisheries (built in Ecopath) and to a thick account (based in focus groups) of what determines the wellbeing of different groups of primary stakeholders (those whose wellbeing is directly affected by changes in ecosystems).

The first step was to reduce to the number of variables of this collective model (Figure S2) to a smaller set of key dynamics. We translated the collective model into a network and applied network analysis to find the nodes that were more central. Figure S3 shows the collective model represented as a network. Each node represents a variable from the collective model. Each link's thickness were represented as the degree of importance that stakeholders associated to that particular linkage (Figure S3) and the degree of uncertainty (Figure S4). 


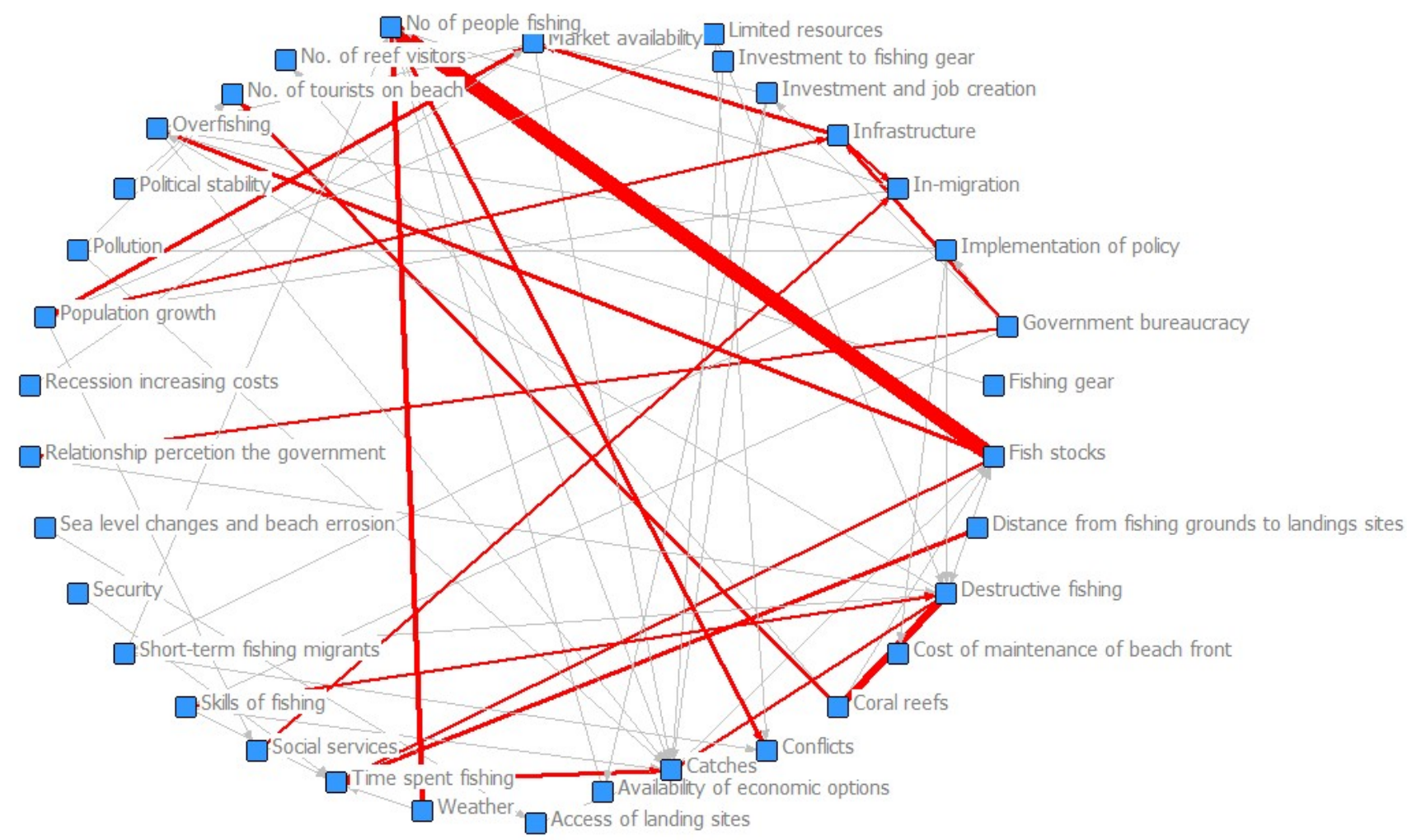

Figure S3. Collective model in a network representation. Links thickness represent degree of importance as identified by stakeholders.

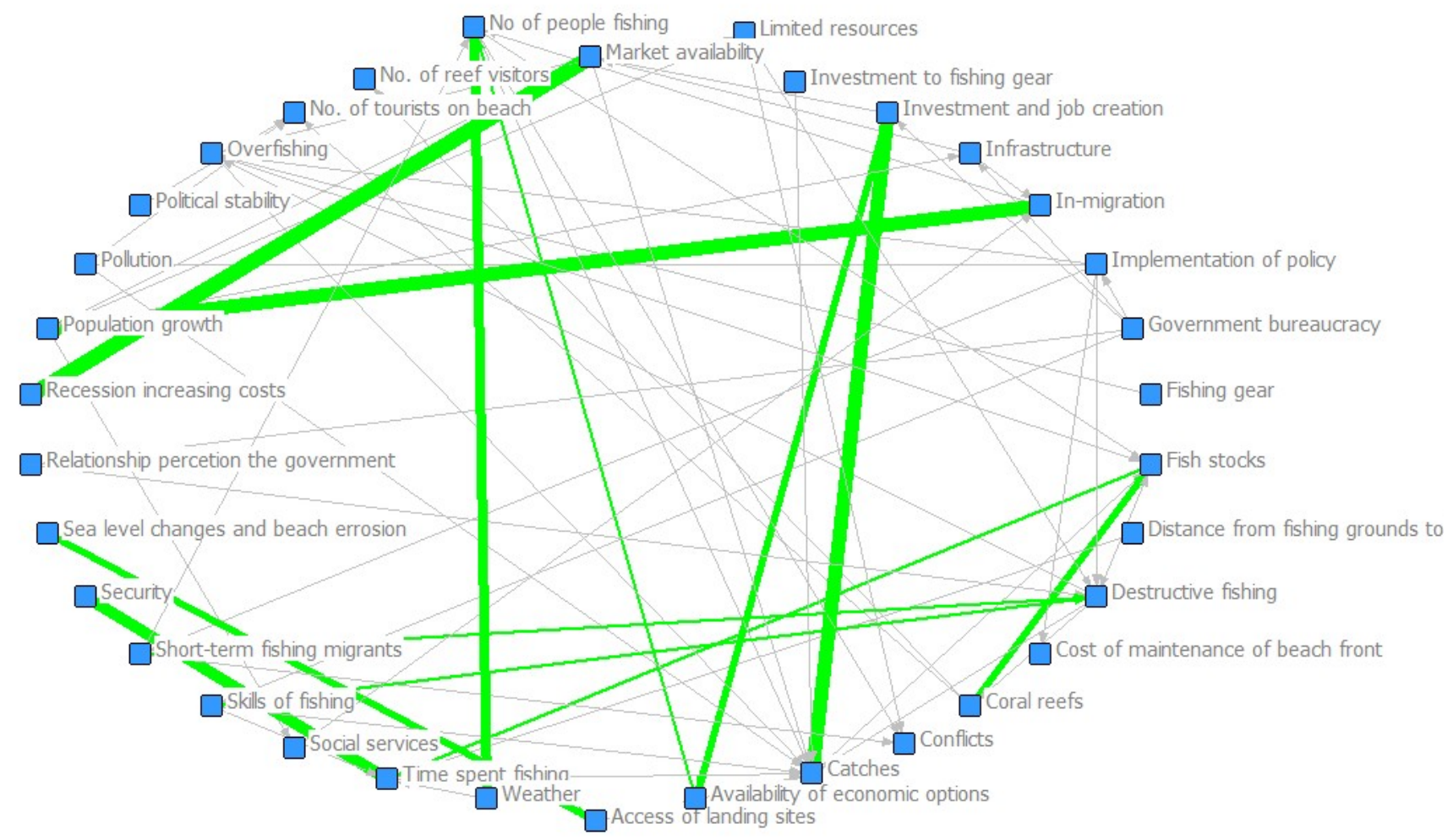

Figure S4. Links thickness represent degree of uncertainty. 
Network analysis allows for the analysis of the directionality of linkages. In other words, if a statement says for instance that "weather affects number of people fishing", we can imagine a directed link going from weather to number of people fishing. In other words, weather is a source and number of people fishing a receiver. With this directional representation we then identified which nodes (components) were more frequently sources and which are more often receivers. In table 1, components are aligned in descendent order according to how important the component is as a source (measured by the number of outgoing links). Then in descendent order according to how important a component is a sink (measured by the number of incoming links). The most important sources can be thought as key drivers of the system. Based on this explorative analysis we created four broad categories (yellow columns in Table 1) that function as an umbrella for several other variables. The categories are governance, population, economy and tourism (Figure S5). Variables related to ecosystem functioning were categorized as Ecopath since their dynamics were incorporated in the detailed ecopath model.

Governance bureaucracy and Implementation of policy are the two components with higher number of links reaching out. This is an indicator that these two particular concepts are important drivers in the network since they affect many other variables (5 each). In the receiver side, the top ranking variables are related to fisheries. This means that fisheries can be seen as being heavily influenced by other factors.

Table S1. Degree analysis of the network

\begin{tabular}{|l|l|l|l|}
\hline $\begin{array}{l}\text { DRIVER } \\
\text { Components }\end{array}$ & Outdegree & Indegree & Category \\
\hline Government bureaucracy & 5 & 1 & Governance \\
\hline Implementation of policy & 5 & 0 & Governance \\
\hline Population growth & 4 & 6 & Population \\
\hline Destructive fishing & 4 & 0 & ecopath \\
\hline Coral reefs & 3 & 4 & ecopath \\
\hline Investment and job creation & 3 & 1 & Economy \\
\hline Short-term fishing migrants & 3 & 1 & Population \\
\hline Skills of fishing & 3 & 1 & ecopath/Gov \\
\hline No of people fishing & 3 & 1 & Population \\
\hline Weather & 2 & 5 & ecopath \\
\hline Limited resources & 2 & 4 & ecopath \\
\hline $\begin{array}{l}\text { RECEIVER } \\
\text { Components }\end{array}$ & Outdegree & Indegree & Category \\
\hline Catches & & & \begin{tabular}{l} 
ecopath \\
\hline Destructive fishing
\end{tabular} \\
\hline Fish stocks & 1 & 10 & ecopath \\
\hline Time spent fishing & 2 & 5 & ecopath \\
\hline
\end{tabular}


Galafassi et al. 2017. "Learning About Social-Ecological Trade-offs".

\begin{tabular}{|l|l|l|l|}
\hline No of people fishing & 3 & 4 & Population \\
\hline Market availability & 2 & 4 & Economy \\
\hline Overfishing & 2 & 4 & ecopath \\
\hline Conflicts & 0 & 3 & population \\
\hline No. of tourists on beach & 0 & 3 & Tourism \\
\hline Infrastructure & 2 & 2 & governance \\
\hline In-migration & 1 & 2 & Population \\
\hline
\end{tabular}

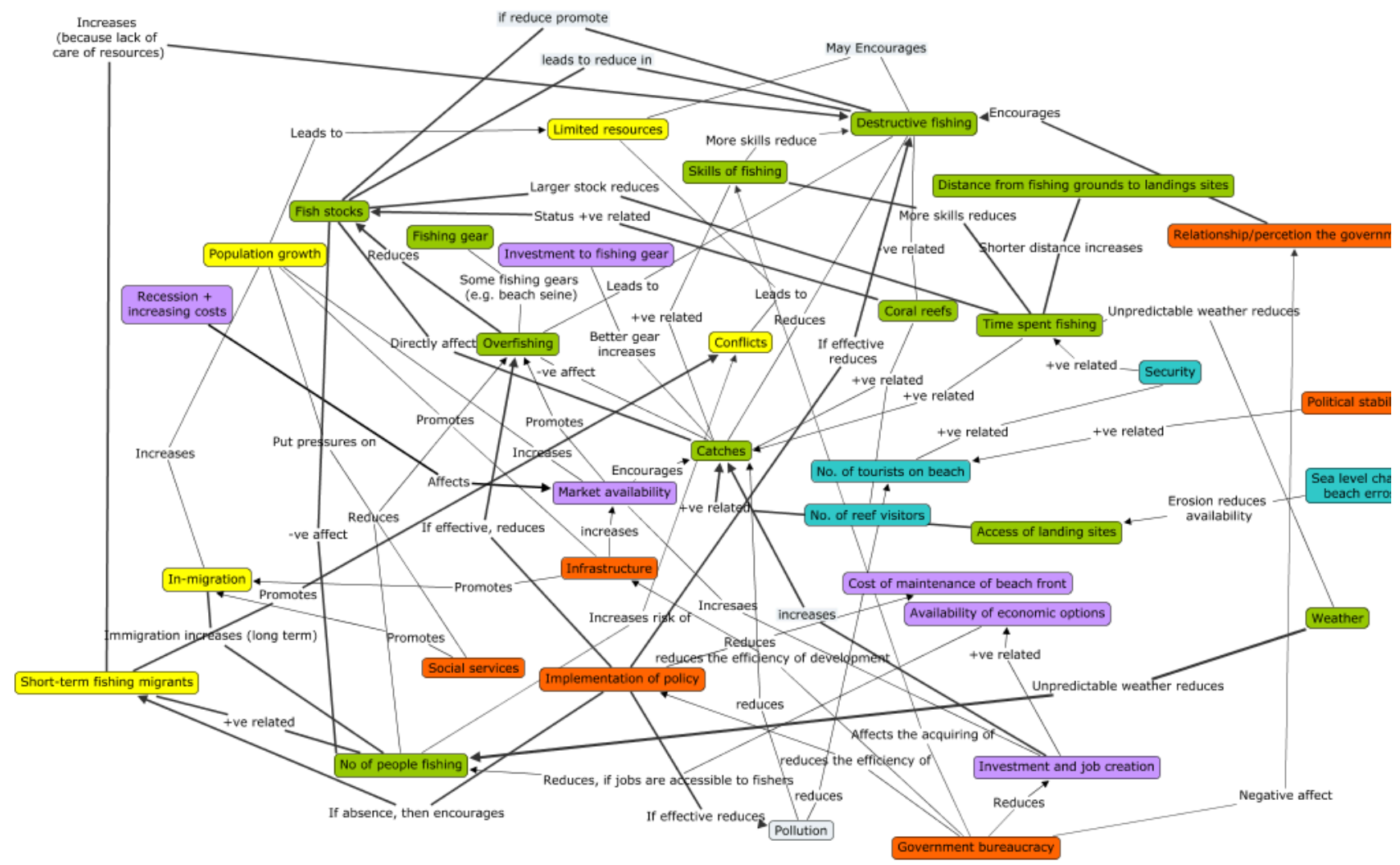

Figure S5. Yellow: Population, Orange: Governance, Purple: Economy, Blue: Tourism, Green: ecology

\section{The model}

This analysis provided the general structure of the model. "Social factors" like 'governance', 'economy', 'population' would drive the ecological dynamics which in turn would affect the wellbeing of different groups. With this structure, the ecological model (built in Ecopath) was 
put at the center of the toy-model. The ecological model (built on Ecopath) has "fishing effort" as key input parameters. For this reason the "social components" of the toy-model were linked to various levels of fishing effort.

Qualitative in-depth wellbeing research was used to model how the wellbeing of various social groups would be affected by the ecological system. Wellbeing research on this case is published in Abunge et al. (2013). The levels of wellbeing was reduced to "earning capacity" in order to link to the quantitative outcomes of the ecological system. Drawing from the qualitative wellbeing research Table 2 specifies the linkages that were identified between "earning capacity" and ecological outputs from the ecological model.

The model was designed in Excel using fuzzy-logic rules to create the linkages between the variable. Results from ecological simulations were exported from Ecopath and built as reference tables in Excel allowing for the linkages with fuzzy-logic rules.

Table S2. Linkages between ecological outputs and primary stakeholders 'earning capacity'.

\begin{tabular}{|c|c|c|}
\hline Stakeholder Group & Ecological output & $\begin{array}{l}\text { How their earning capacity is } \\
\text { affected }\end{array}$ \\
\hline Beach Seine Crew & $\begin{array}{l}\text { Beach seine catch rate (beach seine } \\
\text { CPUE) }\end{array}$ & $\begin{array}{l}\text { Earning capacity is directly linked } \\
\text { to how much they fish and how } \\
\text { much that ecology yields on a given } \\
\text { effort. }\end{array}$ \\
\hline Beach Seine Captain & $\begin{array}{l}\text { Beach seine catch rate (beach seine } \\
\text { CPUE) }\end{array}$ & $\begin{array}{l}\text { Captains own the gear and have } \\
\text { more resources, therefore they are } \\
\text { not as vulnerable to fluctuations in } \\
\text { CPUE }\end{array}$ \\
\hline Other fishers & $\begin{array}{l}\text { Mixed gear catch rate (other gears } \\
\text { CPUE) }\end{array}$ & $\begin{array}{l}\text { Earning capacity directly linked to } \\
\text { CPUE of 'other gears' (speargun } \\
\text { fishing, net fishing) }\end{array}$ \\
\hline Male traders & $\begin{array}{l}\text { High quality fish (biomass output of } \\
\text { certain species and sizes) }\end{array}$ & $\begin{array}{l}\text { Male traders have access to market } \\
\text { in hotels and local restaurants and } \\
\text { usually buy larger size fish. The } \\
\text { actual biomass of fish available at } \\
\text { the beach affects their earning } \\
\text { capacity }\end{array}$ \\
\hline Female traders & $\begin{array}{l}\text { Low quality fish (biomass output of } \\
\text { certain species and sizes) }\end{array}$ & $\begin{array}{l}\text { Female traders usually buy small } \\
\text { fish or certain species that can be } \\
\text { sold in markets. }\end{array}$ \\
\hline
\end{tabular}

\section{Model revision process}

The overall behaviour of the system was evaluated by experts before the second workshop. During the second workshop, on the first day the goals and intentions of the model were 
explained as well as the process that led to the current version. Then, in small groups, participants were guided through each of the linkages that were present in the current version of the model and they were able to suggest modifications either adding or removing links, or defining the strength of each link (Table S3). Based on the suggestions, modifications were done overnight between day 1 and day 2, either in adding/removing fuzzy-logic rules (to add or remove links) or fine tuning the existing rules (to strengthen or dampen the effects of existing rules). It was this collectively revised version that was used during the workshop then to explore the notion of tradeoffs and learn about their implications for policy and management.

Table S3. Model revisions during workshop 2. Adapted from Supplementary material of Daw. et al. 2015

\begin{tabular}{|c|c|c|c|c|}
\hline & Input & Change & Output & Comment \\
\hline & Population & Add Negative Link & Ecosystem & $\begin{array}{l}\text { Population increases in Mombasa } \\
\text { have a direct effect on ecosystem } \\
\text { through habitat degradation and } \\
\text { pollution. }\end{array}$ \\
\hline 2. & Tourism & Add Negative Link & Ecosystem & $\begin{array}{l}\text { Tourism has direct effect on } \\
\text { ecosystem through pollution (e.g. } \\
\text { effluents from swimming pools) }\end{array}$ \\
\hline & Prices & Add Positive Link & $\begin{array}{l}\text { Male } \\
\text { Wellbeing }\end{array}$ & $\begin{array}{l}\text { Price of fish positively affects male } \\
\text { traders because for each fish sold, } \\
\text { there is more profit. }\end{array}$ \\
\hline & Prices & Add Negative Link & $\begin{array}{l}\text { Female } \\
\text { Wellbeing }\end{array}$ & $\begin{array}{l}\text { Above a certain price for fish, } \\
\text { female traders cannot gain access to } \\
\text { the market. }\end{array}$ \\
\hline & Economy & Add Negative Link & Beach Seine Effort & $\begin{array}{l}\text { Economic growth increases } \\
\text { livelihood alternatives for beach } \\
\text { seiners (e.g. construction jobs) }\end{array}$ \\
\hline & Other Jobs & Add Positive Link & $\begin{array}{ll}\text { Other } & \text { Fishers } \\
\text { Wellbeing } & \\
\text { Male } & \text { Traders } \\
\text { Wellbeing } & \\
\text { Female } & \text { Traders } \\
\text { Wellbeing } & \end{array}$ & $\begin{array}{l}\text { Availability of alternative } \\
\text { livelihoods particularly benefits } \\
\text { other fishers and traders because } \\
\text { these groups tend to work in other } \\
\text { jobs available to them whilst } \\
\text { maintaining fishing as a source of } \\
\text { income. }\end{array}$ \\
\hline & Other Jobs & $\begin{array}{l}\text { Change Existing } \\
\text { Link } \\
\text { (Reduce Weight) }\end{array}$ & Beach Seiner Crew & $\begin{array}{l}\text { The strength of the link between } \\
\text { other jobs and beach seiner crew } \\
\text { was weakened to show that beach } \\
\text { seine crew often have little training, } \\
\text { education, or capital to take } \\
\text { advantage of new opportunities. }\end{array}$ \\
\hline
\end{tabular}




\section{SCENARIOS}

In a context of change and uncertainty scenario development is a way to explore possibilities for the future that cannot be predicted by extrapolation of past and current trends.

Based on input from stakeholders during the first workshop in Mombasa, the systems diagrams and discussions, the team created four scenarios of plausible futures for the next 15 years of Mombasa region. These stories were reviewed with local experts and were used as part of the workshop 2 to stimulate discussions on winners and losers under each scenario and potential solutions and mitigation strategies.

Each storyline has a different policy emphasis (drivers), intermediate variables and potential outcome. The purpose in developing these stories was to encourage stakeholders to consider some of the positive and negative implications that the different development trajectories have in the wellbeing of different stakeholders groups. Table S4 summarizes the contrasts between the 4 scenarios.

Table S4. Structuring 'forces' of scenarios

\begin{tabular}{|c|c|c|c|}
\hline Scenario & Policy Emphasis & Intermediate Variables & Initial Outcomes \\
\hline \multirow[t]{2}{*}{ A } & Conservation & Prices & Loss of fish, exclusion of Beach \\
\hline & & Access & Seiners. \\
\hline B & $\begin{array}{l}\text { Welfare-based, } \\
\text { Populist }\end{array}$ & Productivity & More fishers \\
\hline $\mathrm{C}$ & $\begin{array}{l}\text { Development, } \\
\text { Tourism }\end{array}$ & $\begin{array}{l}\text { Prices, Catch, Beach Seine } \\
\text { Effort }\end{array}$ & $\begin{array}{l}\text { Enforcement of beach-seine } \\
\text { ban, less fishing livelihoods }\end{array}$ \\
\hline $\mathrm{D}$ & $\begin{array}{l}\text { Offshore } \\
\text { fisheries }\end{array}$ & $\begin{array}{llr}\text { Decreased fish prices, } \\
\text { decreased effort, coral } \\
\text { bleaching. }\end{array}$ & $\begin{array}{l}\text { Decreased number of fishers, } \\
\text { decreased wellbeing for } \\
\text { inshore fishers. }\end{array}$ \\
\hline
\end{tabular}

\section{Story A - 'Aquaculture’}

\begin{tabular}{l|l|l|l} 
Scenario & Policy Emphasis & $\begin{array}{l}\text { Intermediate } \\
\text { Variables }\end{array}$ & Initial Outcomes \\
\hline A & $\begin{array}{l}\text { Conservation, } \\
\text { Aquaculture }\end{array}$ & $\begin{array}{l}\text { Prices, } \\
\text { Access }\end{array}$ & $\begin{array}{l}\text { Loss of fish, exclusion } \\
\text { of Beach Seiners. }\end{array}$ \\
\hline
\end{tabular}

\section{The story:}

A global recession has impacted the number of international tourists in Mombasa region and the economic growth of Kenya overall. This reduces immigration rates from other parts of Kenya. Local tourist businesses focus on low-volume, eco-tourism rather than mass tourism and there is limited additional of tourism infrastructure. The new government has less emphasis on individual rights and policies are pushed top-down with little engagement with 
local communities. Environmental policies are strictly enforced with the influence of remaining ecotourism operators. The ban on beach seines is strictly enforced displacing fisher folk from this livelihood. Inland and coastal aquaculture begins to develop providing lowincome livelihoods and cheap fish (in competition with coastal fisheries) which persuades more fishers to diversity their livelihood. As a result of the removal of beach seining and reduction in fishing effort, the condition of corals, seagrass, and near-shore fish stocks improve. Those fishers who do remain enjoy high catch rates of high quality (large) fish, but make limited money due to limited demand and competition from aquaculture that has been implemented around Malindi.

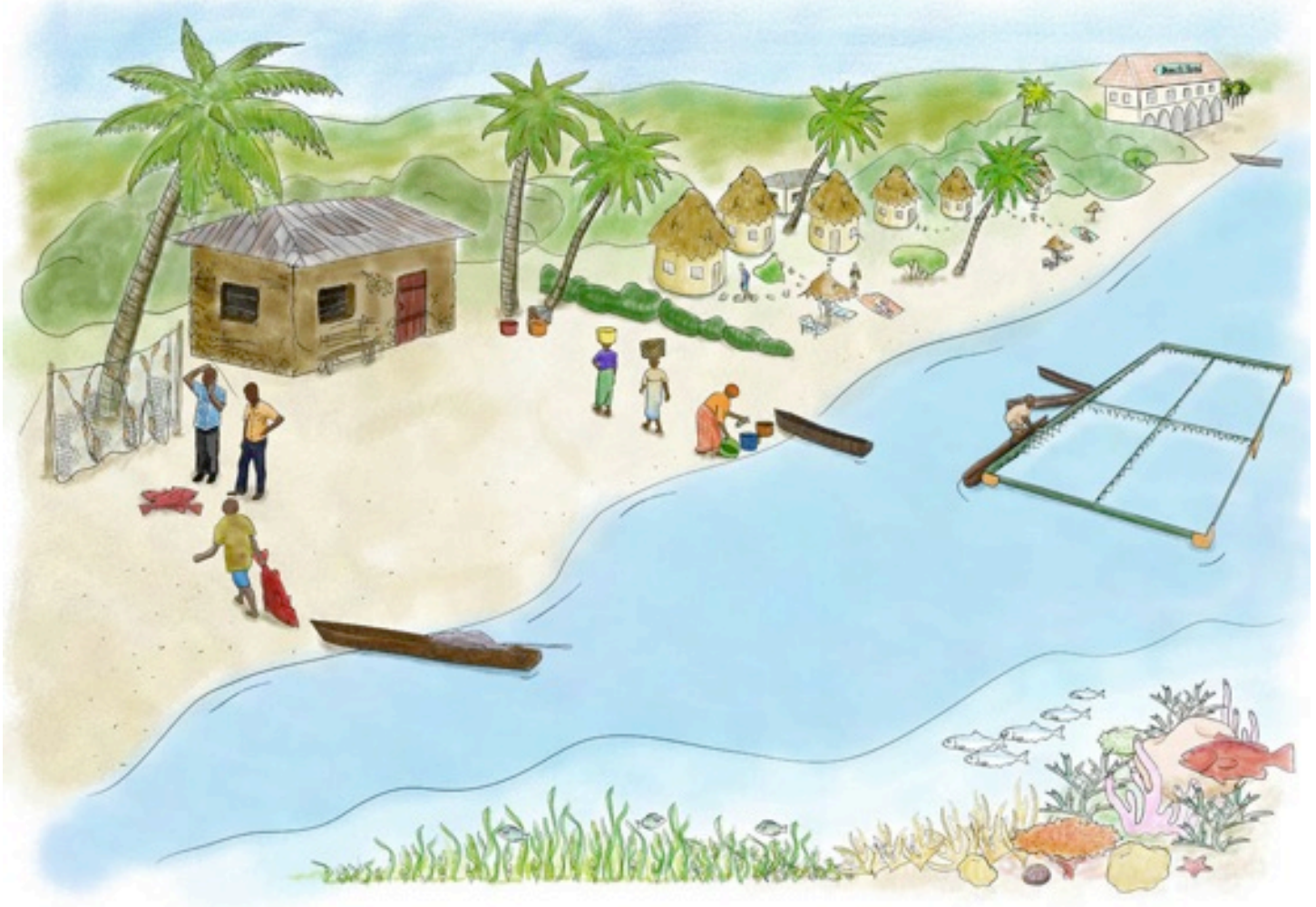

Activity B - Crowded Fishery

\begin{tabular}{l|l|l|l} 
Scenario & Policy Emphasis & $\begin{array}{l}\text { Intermediate } \\
\text { Variables }\end{array}$ & Initial Outcomes \\
\hline B & $\begin{array}{l}\text { Welfare-based, } \\
\text { Populist }\end{array}$ & Productivity & More fishers \\
\hline
\end{tabular}

The story:

A government with strong ideas of inclusion and popular policies has enforced individual rights and community participation. Fisheries are managed by county governments and power is devolved to communities and supported by better healthcare and educational programs. There is a reluctance to enforce environmental regulations which displace livelihoods and a skeptical approach to large development proposals with limited benefits to local people. Meanwhile several years of drought combined with ethical and political tensions in other regions of Kenya have driven people to the coast. Mombasa is a safe haven against problems in other parts of Kenya and because of its newly implemented social policies. 
However few occupation options are available given the low economic growth. Mombasa's tourist industry struggles and low occupancy rates lead to redundancies in the tourism sector. Lacking of other job options many young men enter fisheries, especially as laborers in the beach seine fishery, which is legalized in response to popular demands for jobs and sources of cheap fish. Immigrants also seek work in fish trading and frying. The demand for cheap fish products from the growing local population is high and marines resources are strongly exploited. Fish traders gather around the arriving boats at the beach to find only small and cheap fish in fisherman's nets.

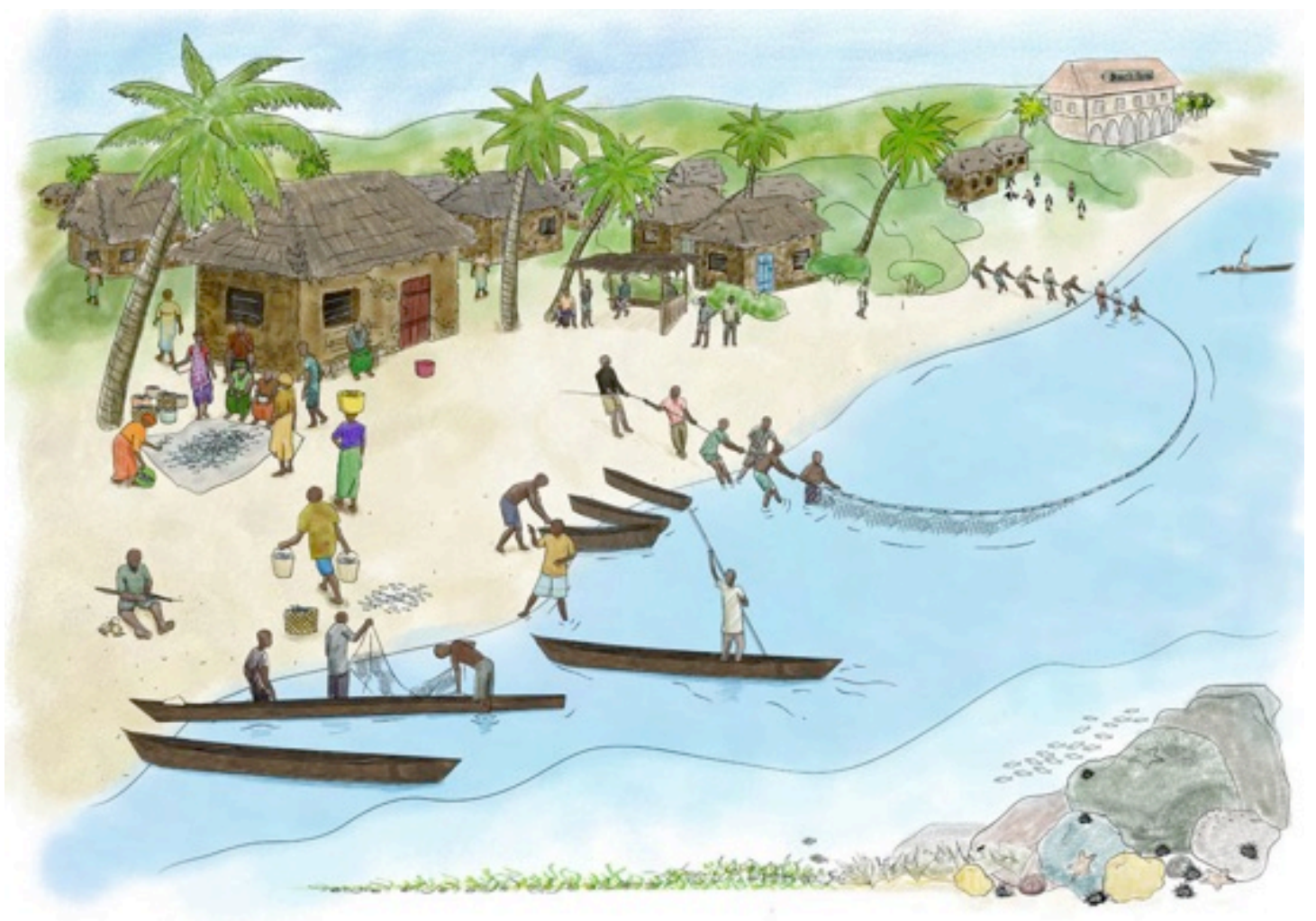

Activity C - Development

\begin{tabular}{l|l|l|l|} 
Scenario & Policy Emphasis & $\begin{array}{l}\text { Intermediate } \\
\text { Variables }\end{array}$ & Initial Outcomes \\
\hline C & $\begin{array}{l}\text { Development, } \\
\text { Tourism }\end{array}$ & $\begin{array}{l}\text { Prices, Catch, Beach } \\
\text { Seine Effort }\end{array}$ & $\begin{array}{l}\text { Enforcement of } \\
\text { beach-seine ban, less } \\
\text { fishing livelihoods }\end{array}$ \\
\hline
\end{tabular}

\section{The story:}

Kenya is enjoying a prosperous phase. A pro-business government and low taxation attracts foreign investments. Mombasa is a reflection of the booming economy with its newly expanded port and influxes of local and international investments that fund infrastructure, hotel investments that promote a growing mass beach tourism market. Port development raises land prices and standard of living. Some fisher folk are attracted out of fisheries into 
opportunities in construction, tourism, and services or as a result of displacement from their landing sites by other economic interests. Those fishers who persist benefit from lowered competition at sea, high demand, and high fish prices. Their catch rates are good and include larger species. Some immigrants find work on beach seine crews that still operate illegally in certain areas. In time, the unconstrained beach development results in beach erosion, which has an impact on tourism and fish landing sites. Conflict between beach seiners and other types of fishers rise. Political tensions are also stoked by increasing levels of inequality as some entrepreneurs get rich and establish exclusive residences along the coast.

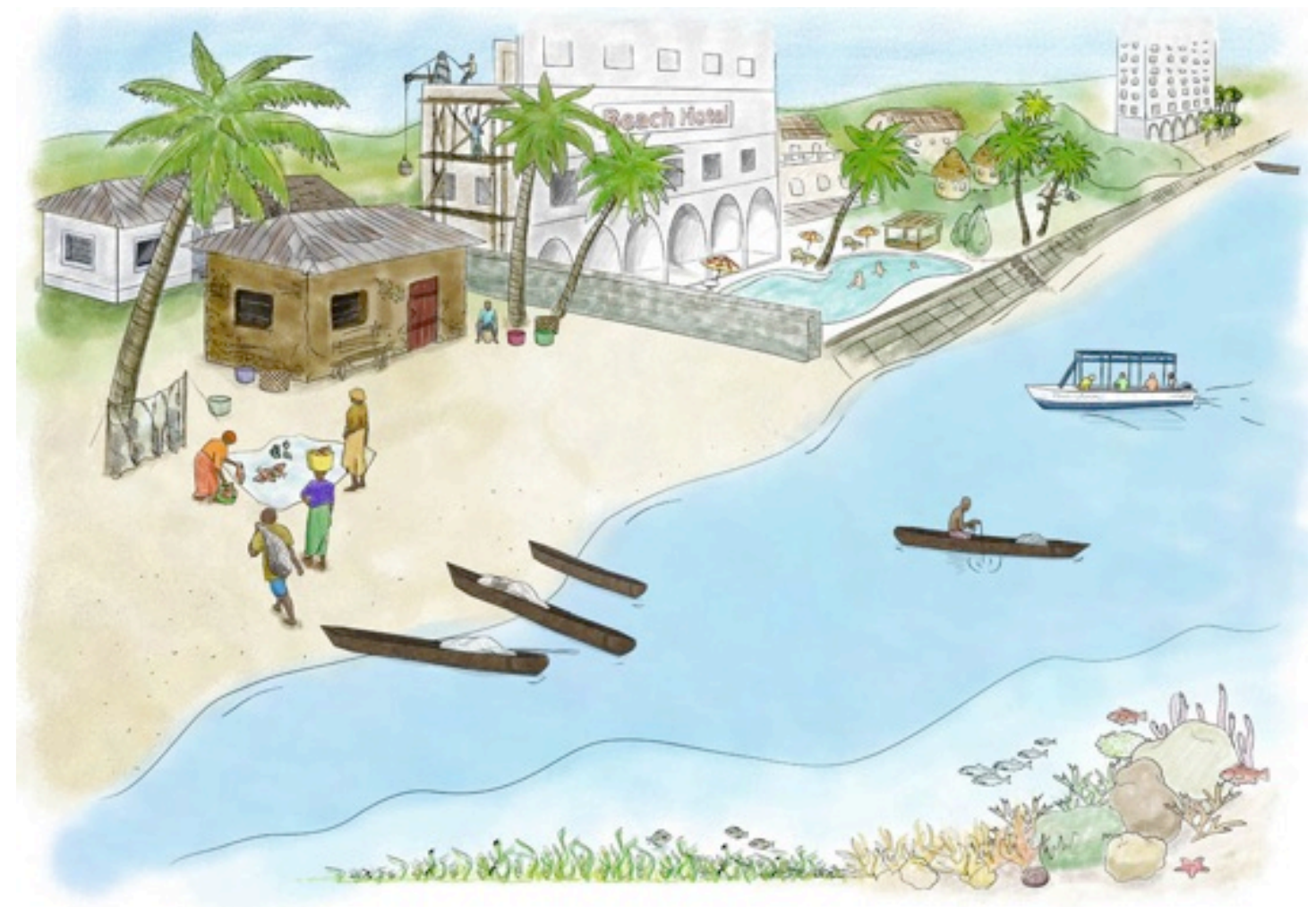

Activity D - Offshore Fisheries

\begin{tabular}{l|lll} 
Scenario & Policy Emphasis & $\begin{array}{l}\text { Intermediate } \\
\text { Variables }\end{array}$ & Initial Outcomes \\
\hline D & Offshore fisheries & $\begin{array}{l}\text { Prices, Effort, Coral Decreased number and } \\
\text { bleaching. }\end{array}$ & $\begin{array}{l}\text { wellbeing of inshore } \\
\text { fishers. }\end{array}$
\end{tabular}

The story: 
Implementation of a project on external donor funding - e.g. Kenya Coastal Development Project - leads to provision of vessels, training, and fisheries marketing infrastructure along the coast by Mombasa. This supports development of an offshore fishery targeting semipelagic deep water fish with modern ring nets and aided by fish finding technology. Initial trials are variable but generally successful and within 5 years 10 large vessels operate from the coast immediately north of Mombasa. These are collaboratively owned by members of fisher organizations and BMUs and crewed by locals as well as migrant Tanzanians as hired laborers and captains. The catches from these vessels are significantly larger than those from smallscale nearshore gears and beach seines, leading to a reduction in the price per kilo of fish landed from the reef and seagrass fishery. The number of fishers using spear, small nets, handline and beach seine reduces due to some fishers receiving training and joining the new

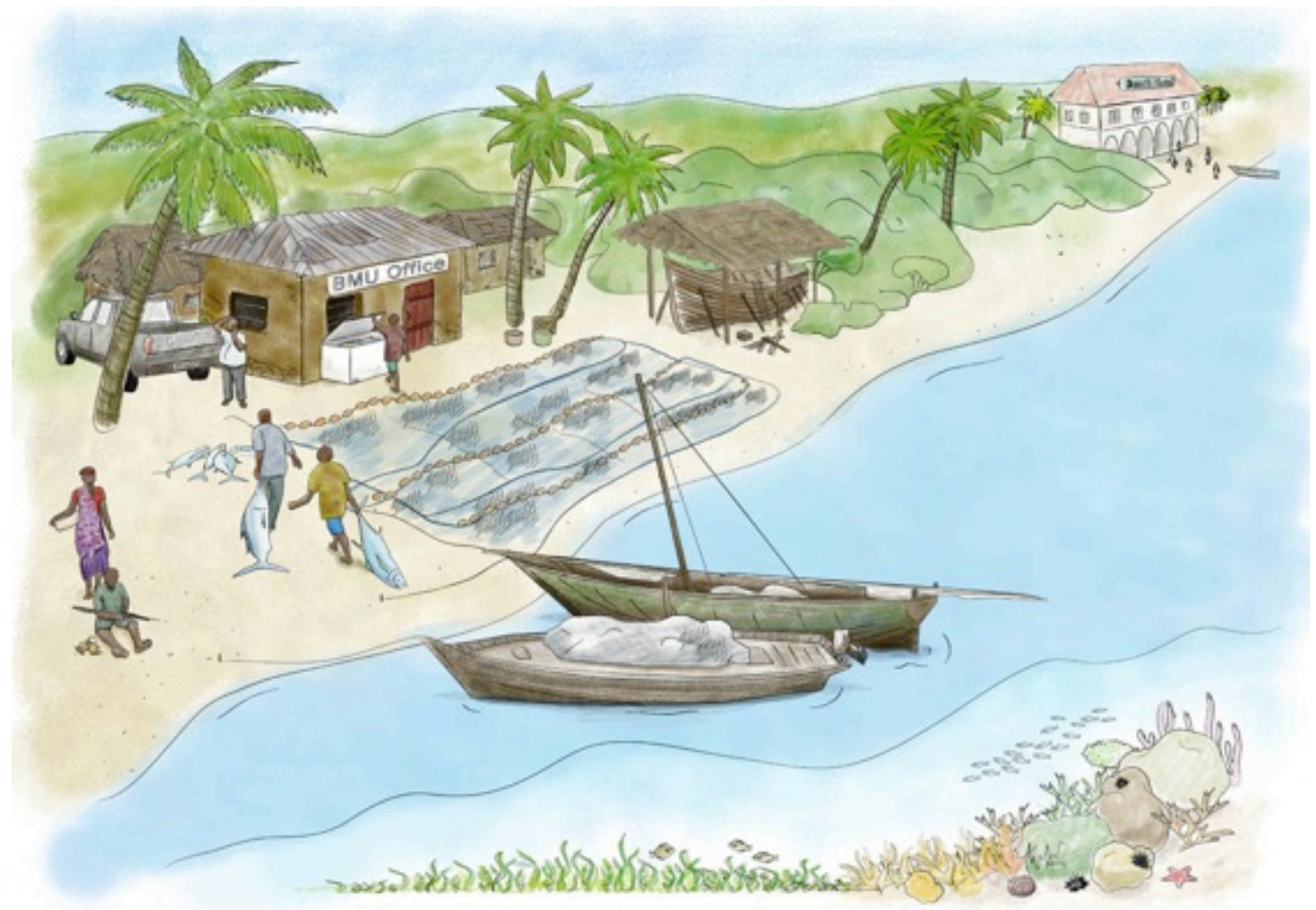

larger vessels, and some opting to leave fisheries in the light of market competition with the new fishery. This leads to a slow recovery of fish in the nearshore habitats, but coral bleaching over repeated years reduces diversity and cover of corals. High catches from the offshore fishery attract investment from local business interests, but fluctuations in catches make it difficult to repay loans on investment several local and community owners have to sell their vessels and operations after poor seasons, or due to lack of financial capital and management. Thus within 10 years the offshore fishery becomes consolidated to be owned by a few larger business people who hire crew from outside the area. Some fishers lose access to this fishery as a result and reluctantly return t0 inshore fishing. 


\section{REFERENCES}

Abunge, Caroline, Sarah Coulthard, and Tim M Daw. 2013. "Connecting Marine Ecosystem Services to Human Well-Being: Insights From Participatory Well-Being Assessment in Kenya." Ambio 42 (8): 1010-21. doi:10.1007/s13280-013-0456-9.

Daw, Tim M, Sarah Coulthard, William W L Cheung, Katrina Brown, Caroline Abunge, Diego Galafassi, Garry D. Peterson, Tim R McClanahan, Johnstone O Omukoto, and Lydiah Munyi. 2015. "Evaluating Taboo Trade-Offs in Ecosystems Services and Human Well-Being." Pnas, May, 201414900. doi:10.1073/pnas.1414900112. 